\title{
The Arid Coastal Wetlands of Northern Chile: Towards an Integrated Management of Highly Threatened Systems
}

\author{
Nuria Navarro ${ }^{1, *(\mathbb{D}}$, Manuel Abad ${ }^{1,2}\left(\mathbb{D}\right.$, Estefanía Bonnail ${ }^{3}(\mathbb{D})$ and Tatiana Izquierdo ${ }^{1,4}$ (i) \\ 1 Departamento de Biología y Geología, Física y Química Inorgánica, Universidad Rey Juan Carlos, \\ C/Tulipán s/n, 28933 Móstoles, Spain; manuel.abad@urjc.es (M.A.); tatiana.izquierdo@urjc.es (T.I.) \\ 2 Corporación de Investigación y Avance de la Paleontología e Historia Natural de Atacama (CIAHN), \\ Avenida Prat, 58, Caldera 1570000, Chile \\ 3 Centro de Investigaciones Costeras de la Universidad de Atacama (CIC-UDA), Avenida Copayapu 485, \\ Copiapó 1530000, Chile; estefania.bonnail@uda.cl \\ 4 Instituto de Investigaciones Científicas y Tecnológicas de la Universidad de Atacama (IDICTEC-UDA), \\ Avenida Copayapu 485, Copiapó 1530000, Chile \\ * Correspondence: nuria.navarro@urjc.es
}

check for updates

Citation: Navarro, N.; Abad, M.; Bonnail, E.; Izquierdo, T. The Arid Coastal Wetlands of Northern Chile: Towards an Integrated Management of Highly Threatened Systems. J. Mar Sci. Eng. 2021, 9, 948. https:// doi.org/10.3390/jmse9090948

Academic Editor: Tom Spencer

Received: 21 July 2021

Accepted: 27 August 2021

Published: 31 August 2021

Publisher's Note: MDPI stays neutral with regard to jurisdictional claims in published maps and institutional affiliations.

Copyright: (c) 2021 by the authors. Licensee MDPI, Basel, Switzerland. This article is an open access article distributed under the terms and conditions of the Creative Commons Attribution (CC BY) license (https:// creativecommons.org/licenses/by/ $4.0 /)$.

\begin{abstract}
The ecological value of coastal wetlands is globally recognized, particularly as biodiversity hotspots, but also as buffer areas because of their role in the fight against climate change in recent years. Most of Chile's coastal wetlands are concentrated in the central and southern part of the country due to climate conditions. However, northern coastal wetlands go unnoticed despite being located in areas of high water deficit (desert areas) and their role in bird migratory routes along the north-south coastal cordon of South America. This study reviews the current environmental status of the arid coastal wetlands of northern Chile (Lluta, Camarones, Loa, La Chimba, Copiapó, Totoral, Carrizal Bajo) in terms of regulations, management, and future aims. The main natural and anthropogenic threats to these coastal wetlands are identified, as well as the main management tools applied for their protection, e.g., the Nature Sanctuary designation, which allows for the protection of both privately and publicly owned property; and the Urban Wetland, a recently created protection category.
\end{abstract}

Keywords: coastal wetlands; Atacama Desert; management tools; Ramsar; nature sanctuary

\section{Introduction}

Coastal wetlands are aquatic ecosystems that sustain rich biodiversity and provide important ecosystem services, as defined by the Convention on Wetlands (Ramsar, Iran, 1971 [1]). They are areas of high ecological value, where terrestrial and marine environments converge, sharing various characteristics and threats to which they are exposed [2]. In Chile, with almost $6500 \mathrm{~km}$ of coastline, the distribution of coastal wetlands decreases in latitude from south to north, where they emerge scattered along the coastal area, forming a valuable corridor with high biodiversity, productivity, and endemism. They bear considerable relevance for ecosystem services, providing the coastal population with fisheries habitats, carbon sequestration, water filtration, and sediment trapping [3,4]. Moreover, they are essential as refuges for a wide variety of species of flora and migratory birds that migrate along the "Pacific-West", "Central", and "Patagonia" flyways [4], meaning its connectivity is indispensable.

These coastal wetlands are exposed to a wide range of threats of both natural and anthropogenic origin that have a potential dramatic impact upon their biodiversity and geomorphological configuration [5]. These cause northern Chile coastal wetlands to be in a critical condition in terms of vulnerability, resilience, and sustainability, aggravated by the current global changes [6]. Consequently, it is vital and urgent to devise distinct environmental protection categories ensuring the conservation and preservation of these systems 
of high ecological value [7]. Coastal wetlands develop in very dissimilar physiographic, hydro(geo)logical, and climatic contexts, giving them very heterogeneous features that generate varying degrees of vulnerability, resilience, or differential responses to threats. Thus, in territories marked by profound transformations in their geography, climate, and degree of anthropic occupation, as is the case in Chile, there are unanticipated differences among the coastal wetlands. This creates different scenarios of vulnerability that may not be contemplated, or sufficiently nuanced, by the environmental protection regulations, creating situations in which the safeguarding of these natural systems and, finally, their conservation are not guaranteed.

Arid coastal wetlands have been mainly studied for their ecological, edaphic, and hydrogeological features [8-10], whereas studies focused on their management and conservation are more scarce compared with those of temperate and tropic wetlands. The reason behind this difference is that they represent complex hydrogeological systems in which small changes in their hydrological regime can cause modifications in the groundwater chemistry, in the development of the soil profile, in the vegetation, etc. [11,12]. In fact, even though the ever-increasing water demands of industry and agriculture, coupled with the sensitivity of the wetlands to the irregular hydrographic conditions characteristic of arid and semiarid zones, renders them particularly vulnerable, they have received little attention in recent scientific literature (e.g., $[13,14])$.

In northern Chile, these coastal systems have a very precarious equilibrium, dependent on the maintenance of freshwater flows from river basins. At present, those river basins are subject to interventions by human activity, primarily caused by the overexploitation of aquifers by agricultural and mining activity. Furthermore, these arid coastal wetlands are severely threatened by a wide variety of both natural (winter storms, tsunamis, sealevel rise, and droughts) and anthropogenic processes (urban sewage, industrial waste, the advancement of agricultural and urban borders, the effect of introduced species and irrigation ditches, clandestine landfills, and the lack of legal and practical mechanisms ensuring the future viability of the few currently protected wetlands). These both seriously jeopardize their conservation in the coming decades $[4,15]$. As a result, the wetlands located in one of the most arid areas of the world, the Atacama Desert, may well be considered ecosystems in a fragile condition.

Because of the sparse distribution of coastal wetlands in northern Chile and their crucial ecological relevance, this study aims to highlight their meaning and significance despite having been poorly studied from a holistic perspective. In fact, so far, the analysis of their ecological, geomorphological, and hydro(geo)logical features, integrated with the threats they are exposed to, their environmental degradation, their heritage value and their legal protection, has not been previously carried out. Therefore, the main objectives of this work are (i) to review their recent environmental history; (ii) to catalogue and assess the different threats to which they are exposed; and (iii) to evaluate whether the Chilean environmental legislation has considered the particularities of these ecosystems and its adequacy and sufficiency to ensure their continuity in the short and long term. These coastal-marine spaces are valuable not only environmentally, but also socio-culturally. They have been strongly connected with the history of the occupation and use of the territory by humans for thousands of years until the last decades, when the recent population growth and the anthropogenic pressure has put coastal wetlands of northern Chile at risk [16].

\section{Materials and Methods}

A review of the available literature was made in terms of vulnerability factors, threats, legal framework, and coastal management tools applied to northern Chile coastal wetlands. The main instrument for information analysis was the National Inventory of Wetlands 2020 [17] that georeferenced all of the wetlands of Chile. The database was used for the identification of the wetlands, determining their location, characteristics, and distances, along with other international databases, such as the Ramsar site list. The legal framework consultancy was obtained through the National Congress Library (BCN). Moreover, the 
gray literature contained in the different ministries was also reviewed. In most cases, these unpublished government reports were the only available information source, in addition to undergraduate or graduate theses from local universities. For the scientific literature review, we used the customary academic databases.

\section{Coastal Zone Management: Legal and Institutional Framework}

The state of Chile shows a centralizing tendency that has dominated national decisions since individual regions have historically had a relatively minor role in decisionmaking [18]. Likewise, administrative organizations range from those at a national scale, managing the coast and its resources, and those at a local scale, responsible for planning and managing land use [19]. The result is that policymaking is distributed among a vast number of institutions of which the territorial planning regulations are designed to regulate urban territory more efficiently than non-urban territory, generating differences in the effectiveness of regulation, being particularly noticeable on the coast [20].

The administration of the coastal edge corresponds to the Ministry of National Defense, which exercises the control, inspection, and supervision of the coast and territorial sea of Chile (Figure 1, Table S1). It has the ability to grant concessions for the use of the coastal zone, making it one of the most relevant institutions in the organization of the coastal edge [18]. In 1994, the National Policy on Coastal Edge Use (PNUBC) was approved, representing the first step towards coastal zone management. The coastal edge was defined as the territorial zone that includes land and sea extending from the highest tidal line 80 $\mathrm{m}$ towards the land and 12 miles towards the sea. It includes beach lands, beaches, bays, gulfs, straits, inland channels, and the entire territorial sea of Chile [18]. The essential planning instruments of the PNUBC are constituted by the National Commission on Coastal Edge Use (CNUBC), comprising representatives of several ministries and governmental agencies with competence in the coastal edge [21], the function of which is to define coastal zoning [22]. The CNUBC established that the fourteen coastal regions of Chile should carry out its coastal zoning by means of the Regional Commissions on Coastal Edge Use (CRUBC). In 2018, competences were granted to the Regional Governments (GORE) regarding land-use planning through a new territorial planning instrument, the Regional Territorial Ordering Plan (PROT) [5], which defines the preferential uses of the coast at a regional level. Other government agencies also have competences in the administration of the coastal edge. The General Directorate of the Territory and the Merchant Marine (DIRECTEMAR) is responsible for complying with the laws and international agreements in force in the maritime area of its jurisdiction. Similarly, the National Fisheries and Aquaculture Service (SERNAPESCA) oversees compliance with fisheries and aquaculture regulations and exercises the supervision of Marine Parks and Reserves (Figure 1). 


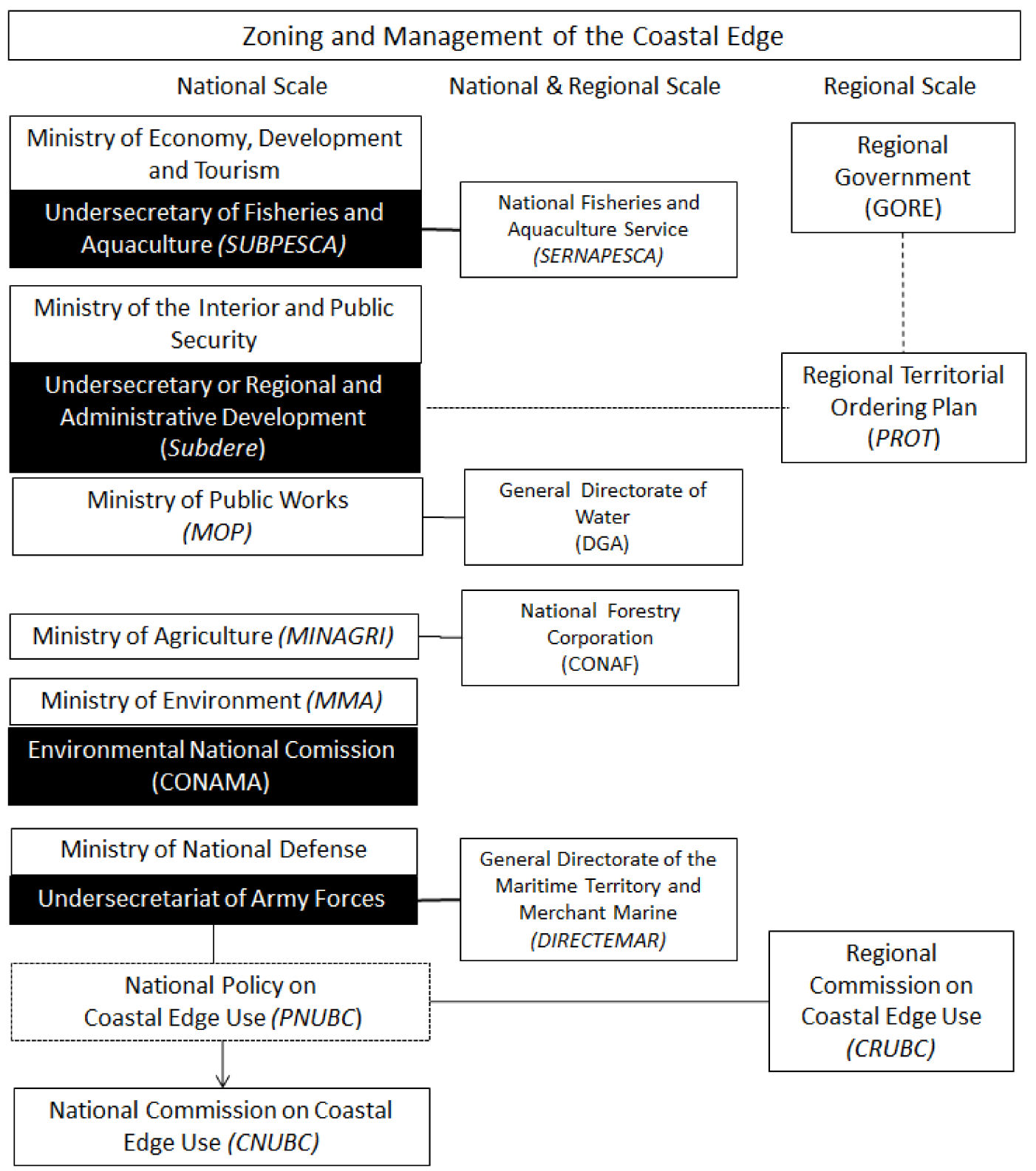

Figure 1. Institutions involved and areas of action in the coastal zone management.

When authority over protected areas in coastal zones are considered, the number of institutions involved increases (Figure 1, Table S1). The National Forestry Corporation (CONAF) administers the National System of Protected Wild Areas of the State (SNASPE), with a specific program for the conservation of wetlands (National Program for the Conservation of Wetlands within SNASPE [23]), in which the northern coastal wetlands were not included. The Ministry of the Environment (MMA) manages the Multipurpose Coastal Marine Protected Area (CMAPMU), guards the Nature Sanctuaries (SNs) and supervises the entire system of protected areas.

Chile has acquired some international compromises that have promoted several national and regional regulations to protect the coastal wetlands (Table S1). The Ramsar Convention (1971) has been acknowledged by the Chilean Government since 1981 through Decree 771 of the Ministry of Foreign Affairs. Chile currently hosts sixteen sites designated as Wetlands of International Importance (Ramsar sites), which implies a surface area of 363,927 hectares. Although Ramsar sites are highly variable, coastal wetlands have gained greater relevance in recent years due to their ecological, geological, and chemical role in the fight against climate change; and the consequences of other natural events occurring 
in Chile (e.g., tsunamis, flood mitigation, droughts, etc.). The last designated Wetlands of International Importance have been coastal wetlands: Tongoy Bay (Coquimbo, 2018), Monkul wetland (Araucanía, 2020), and Limari River, from Salala to its mouth (Coquimbo, 2020). There are only eight designated Ramsar sites classified as marine or coastal wetlands in Chile, equalling 69,315 ha [24]. However, none of them is located in northern Chile. Hence, it is imperative to pinpoint that the absence of protection categories, such as Ramsar sites, exposes these areas to fragmentation and puts at risk coastal migration routes (i.e., threats for bird nesting and migration).

The MMA manages the National Plan for Wetland Protection 2018-2022 [25] (Table S1), which aims to stop the detriment of wetlands and to preserve biodiversity (protection of 40 wetlands $/ 250,351 \mathrm{ha}$, including some coastal wetlands). Each wetland will be associated with a protected area category (Figure 2) and will be accompanied by regulations and institutions responsible for its protection [25]. In Chile, there are nine official protectedarea categories that meet the following criteria: (i) biodiversity conservation; (ii) have management plans and; (iii) have institutional mechanisms for their planning, designation, and management [26] (Figure 2). In conjunction with these official categories, there are other conservation instruments such as international protection categories or other protective categories that are not protected areas. Some examples include buffer zones, conservation landscapes, biological corridors, and priority sites for biodiversity conservation (Figure 2). Recently, several northern coastal wetlands have been included in the National Plan for Wetland Protection 2018-2022. The main category used is Nature Sanctuary (Law 17.288 [27]), which is the only category that allows for the protection of both privately and publicly owned property, making it a flexible model. The Ministry of Cultures has the authority to declare the areas that are protected under this category, as well as the power to authorize the projects and/or activities that are carried out in them; yet it does not have the competence to administrate these areas. They are under the custody of the MMA. Nature Sanctuaries are considered in the same way as any terrestrial or marine sites with distinct possibilities for geological, paleontological, zoological, botanical or ecological studies, and research; or containing natural formations that should be reserved for scientific or governmental interest. The category of Nature Sanctuary for wetlands requires, among other things, "that all work execution, programs or activities to be developed inside and that are likely to cause environmental impact must be submitted to the Environmental Impact Assessment System (SEIA). In other words, projects require permits that ensure the object conservation of the protected areas" [28].

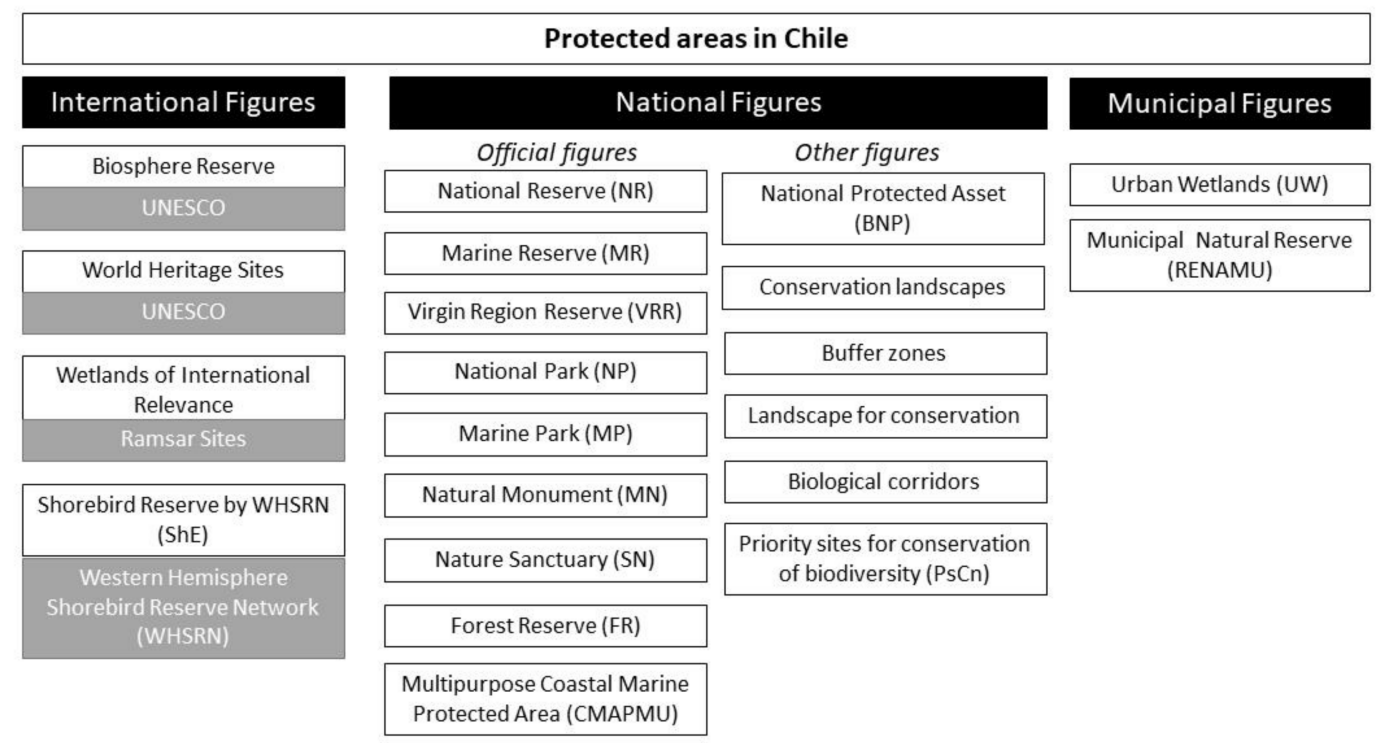

Figure 2. National and international protection categories in Chile. 
In 2020, the sustainability of the urban wetlands was considered under Law 21.202 [29] (Table S1), whereby the Ministry of Public Works (MOP) and the MMA will establish the minimum criteria to preserve their ecological characteristics and functioning, and the maintenance of the hydrological regime, both surface and underground. This law provides municipalities with concrete tools that will allow the protection of urban wetlands, by the drafting of General Ordinances for the protection of urban wetlands and the postponement of permits for property subdivision, urbanization, and construction.

\section{The Arid Coastal Wetlands of Northern Chile}

In this study, we focused on seven coastal wetlands of northern Chile: the Lluta (LLU) and Camarones (CAM) rivers' mouths in the Arica and Parinacota Region; the Loa (LOA) river mouth and La Chimba (CHI) in the Antofagasta Region; and the Copiapó (COP) river mouth, Totoral (TOT); and Carrizal Bajo (CAR) in the Atacama Region (Figure 3). The extreme aridity of these regions, with a De Martonne aridity index (IDM) [30] lower than 0.5 , makes them highly sensitive to natural or anthropogenic changes. Thus, a review of their threats and their legal protection status is key, and urgent to guarantee their future. Other arid wetlands located in the southern Atacama Desert coast with higher IDMs (e.g., the Huasco wetland with IDM 1.45) or without an abundant supply of surface or groundwater (e.g., Mejillones Bay) have not been considered in this work. Finally, after the 2015 extreme hydrometeorological event, the Salado River eroded the beach located at its mouth and two new lagoons were formed that are currently being vegetated [31,32]. This newly formed wetland was not included either, awaiting its evolution in the dynamic littoral system.

The studied coastal wetlands are distributed along more than $1000 \mathrm{~km}$ of coastline, covering four Chilean territorial macrounits (regions), all of them located on the Atacama Desert coast from $18^{\circ} \mathrm{S}$ to $28^{\circ} \mathrm{S}$ (Figure 3). This coastline is classified as mixed semidiurnal and microtidal, with a mean tidal range of $\sim 0.9 \mathrm{~m}$. The dominant swell direction is $\mathrm{SW}$, with significant wave heights of 1.79-2.04 m [33]. Specifically, data collected on the coast of the Chilean Atacama Desert by Campos et al. [34] indicate that the average and most frequent source of storm swell is from the southwest, accompanied by noticeable average wave heights close to $3 \mathrm{~m}$, with maximum values of $5 \mathrm{~m}$, that is, considerably lower values than the rest of the Chilean coastline. However, the analysis of the storm significant height extreme values projections shows a considerable significative increase in this parameter for the coming decades [35].

From a geodynamic perspective, the subduction margin of the Nazca plate beneath the South American plate along northern Chile is considered among the major seismic gaps worldwide. Convergence along this large tectonic margin occurs in a northeastern direction at a rate of $\sim 65-67 \mathrm{~mm} / \mathrm{yr}$ [36] and may be regarded as a highly coupled interplate subduction contact [37]. Along this major seismic gap, great numbers of tsunamigenic earthquakes of moderate magnitude (Mw 7-8.5) have occurred in the last centuries (the most recent the $2014 \mathrm{CE} \mathrm{Mw} \mathrm{8.2} \mathrm{event).} \mathrm{The} \mathrm{major} \mathrm{and} \mathrm{most} \mathrm{highly} \mathrm{destructive} \mathrm{events}$ were the $1420 \mathrm{CE} \mathrm{Mw} \mathrm{9,} \mathrm{the} 1868 \mathrm{CE} \mathrm{Mw} \mathrm{8.6-8.8,} \mathrm{the} 1877 \mathrm{CE} \mathrm{Mw} \mathrm{-8.8-8.9,} \mathrm{and} \mathrm{the}$ 1922 CE Mw 8.6 events, with associated run-ups between 8-20 m a.s.l. These extensive interpolate seismic events produce substantial ecosystemic and geomorphologic damages [38-41], as well as considerable tectonic uplift (>1 m) of some coastal segments, which may consequently drastically affect coastal wetlands [42,43]. 


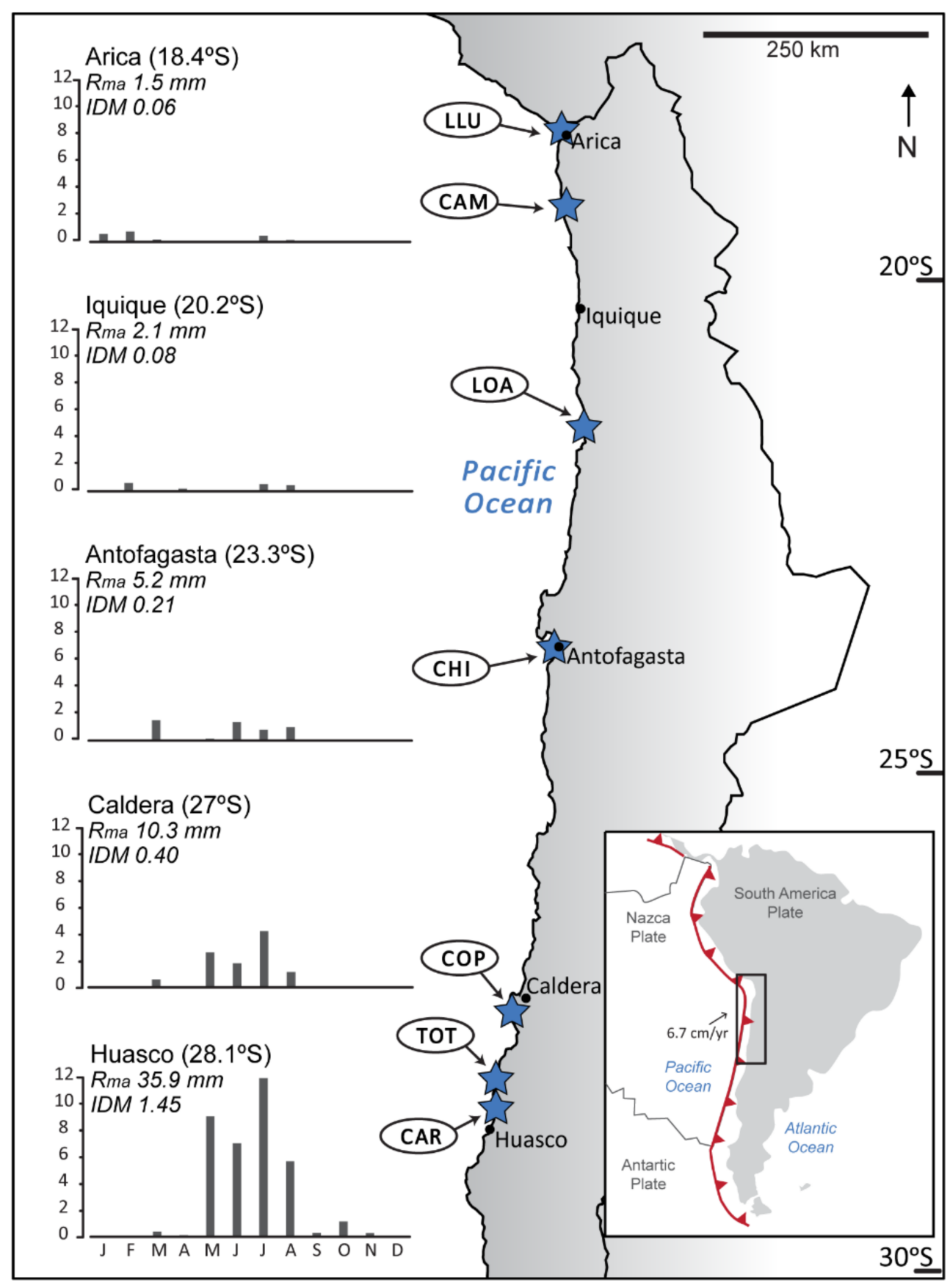

Figure 3. Location of the studied coastal wetlands in northern Chile: LLU, Lluta; CAM, Camarones; LOA, Loa; CHI, La Chimba; COP, Copiapó; TOT, Totoral; CAR, Carrizal Bajo. The graphs show monthly rainfall (2010-2020) for the main coastal cities in mm (DGA: www.dga.cl, accessed on 28 June 2021); Rma: annual rainfall (DGA: www.dga.cl, accessed on 28 June 2021); IDM: De Martonne aridity index [30].

The geomorphology of the coastal area of the Atacama Desert is characterized by the presence of various Pleistocene marine terrace levels with heights between the current sea-level and $250 \mathrm{~m}$ a.s.l. (e.g., [44,45]). These terraces develop in the western foothills of the Andes Range, defined here by the Coastal Range, formed by Palaeozoic metamorphic rocks and Mesozoic sedimentary rocks intruded by plutonic igneous rocks. The Coastal Range constitutes an orientated N-S relief with variable widths of 10 to $25 \mathrm{~km}$, which is intermittently cut by ravines of episodic and torrential behavior, as well as small rivers 
that reach the coastline. These latter features define very incised and narrow river valleys, where the occurrence of wetlands is possible.

The study area is an intertropical arid area that belongs to the biogeographical province of the Coastal Desert, dominated by the influence of the southeast Pacific subtropical anticyclone and modulated by the El Niño southern oscillation (ENSO), with a two- to seven-year periodicity, and the Pacific decadal oscillation (PDO), with 20- to 30-year periods $[46,47]$. The Atacama Desert's extremely arid conditions are controlled by the presence of the Coastal and Andean Ranges [48], the cold oceanic waters of the Humboldt current system [49,50], and the southerly wind-driven coastal upwelling events occurring throughout the year [49,51]. Rainfall in the study area tends to increase with latitude [52] with mean annual values that range from $1.5 \mathrm{~mm}$ in Arica (18.4 $\mathrm{S}$ ) to $35.9 \mathrm{~mm}$ in Huasco $\left(28.1^{\circ} \mathrm{S}\right)$, south of the study area [53] (Figure 3). Despite coastal fog, a distinguishable feature of the local climate that provides water to a hyperarid environment and isolated ecosystems (e.g., [54-57]), the area is classified as hyperarid as the IDM is $<0.5$ [30]. Thus, desertic landscapes with coastal xerophilic scrub dominate as vegetation is scarce except along the transverse (east-west) valleys of the rivers that flow from the Andes range to the Pacific Ocean, crossing the desert and fed at high altitudes [4]. Along this coastline of arid northern Chile, small wetlands appear scattered around the mouths of river valleys and streams, fed by small springs or surface waters of very limited flows. Therefore, the presence of the coastal wetlands acquires a special importance as a connective network, drought combat, geophysical barrier, and the host of a huge number of endemic species [58].

The studied coastal wetlands have a total area of 1962 ha (Figure 4). In general, their area does not become larger toward less arid conditions, i.e., higher latitudes, since their formation and surface area are mainly controlled by surface and groundwater supply. This factor is then conditioned by the physiography, the hydrogeology, and the features of the watersheds, including human intervention in the upper sectors of the basins. Hence, the most important wetlands are those with higher watershed extensions- the Lluta, Camarones, and Copiapó wetlands, which represent a sharp increase in the accumulated area, shown in Figure 4. The other coastal wetlands, generally with areas below 50 ha, correspond to systems located at the mouths of episodic ravine or springs. In the case of the Loa River, even though it is one of the longest rivers in Chile, the groundwater extraction and the intervention of its channel over the last decades has led to the occurrence of a coastal wetland with a very limited area of only 30 ha [15]. 


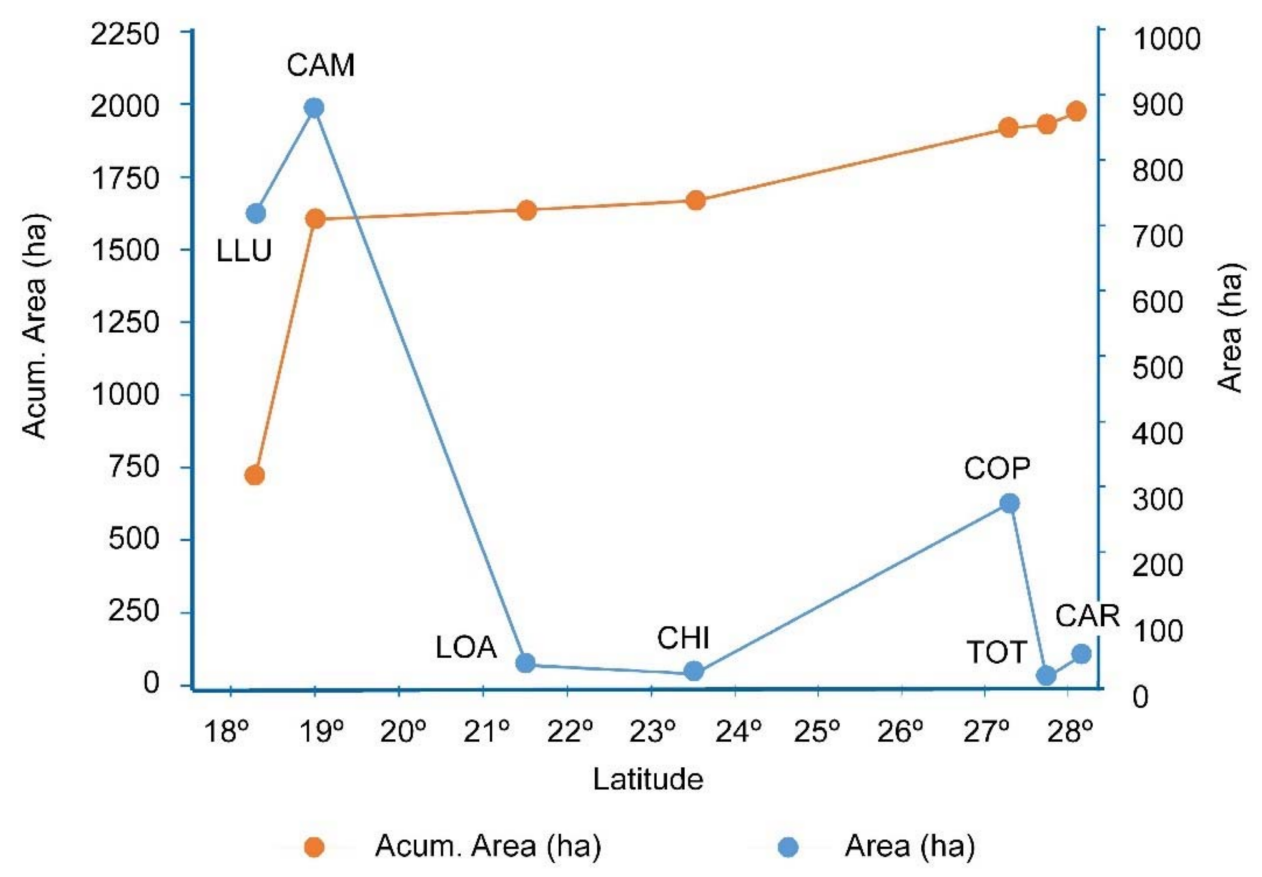

Figure 4. Area and accumulated area of the wetlands analyzed in this work according to latitude. The abbreviated name of the wetlands is located over its area (see Figure 3).

\subsection{Lluta River Wetland}

The Lluta river is an exoreic river that exhibits its most important floods due to the highland winter rains [15]. It has a length of $147 \mathrm{~km}$ and covers an area of $3378 \mathrm{~km}^{2}$ (Figure 5A). It has scarce vegetation in the upper part of the basin that increases in the lower parts. Its medium discharge rate in the river mouth is $1.4 \mathrm{~m}^{3} / \mathrm{s}$, with quantified minimum values of $0.09 \mathrm{~m}^{3} / \mathrm{s}$, whereas the medium flow rate entry is $2.5 \mathrm{~m}^{3} / \mathrm{s}$ [59]. On the other hand, during very rainy years, especially those associated with ENSO events, its conditions may vary violently, with outflows of up to $4.5 \mathrm{~m}^{3} / \mathrm{s}$.

Its mouth forms a wetland of approximately 300 ha with an extensive sandy beach (Figure 5A), only a few kilometers from the city of Arica and near the border with Perú. It can be categorized as an urban wetland in which a lagoon arises before the river mouth, disconnected from the sea by a sandy barrier on which a long foredune is formed [4]. This wetland favors the presence of 154 bird species, which represents $32 \%$ of the bird species described for Chile, and it is known to serve as a resting and nesting site for migratory birds from North America [15]. It hosts more than 20,000 shorebirds, including two South American endemic shorebird species: the Peruvian thick-knee (Burhinus superciliaris) and white-backed stilt (Himantopus melanurus). The mouth of the Lluta River is also a vital part of the life cycle of river shrimp (Cryphiops caementarius). Moreover, aquatic macrophyte vegetation supports the important biodiversity of aquatic insects and molluscs. Other species characterized as extinction risks, such as the cactus Copiapoa tocopillana and the fish Basilichthys semotilus (pejerey), may well be found in this wetland [60]. Thus, the Lluta river wetland should be considered the most relevant in northern Chile in terms of biodiversity, standing out for its high number of species and concentration of individuals. The reason behind this uniqueness is that this wetland is the satellite of the extensive Ite wetland (Tacna, Peru), from which short-term migrations to Lluta are generated [15]. 


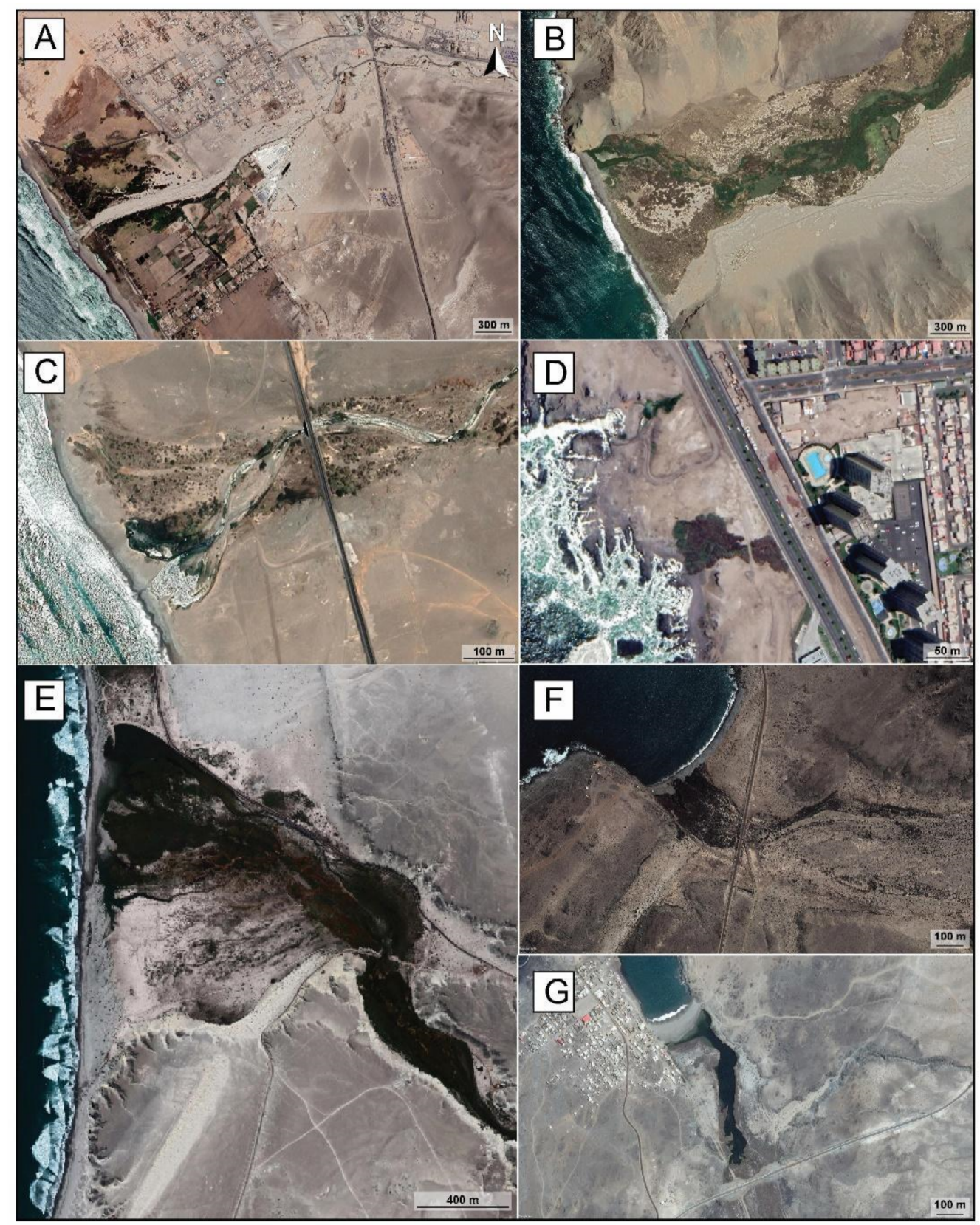

Figure 5. Satellite images of the coastal wetlands analyzed in this work. See location in Figure 3. (A) Lluta river wetland; (B) Camarones wetland; (C) Loa river wetland; (D) Chimba wetland; (E) Copiapó river wetland; (F) Totoral wetland; (G) Carrizal Bajo wetland. Source: Google Earth Pro.

The Lluta river mouth wetland was included in the list of 68 Priority Sites for the Conservation of Biodiversity in 2003 and, in 2009 was declared a Nature Sanctuary [61], protecting an area of 30.64 ha. In 2010, it was designated as a shorebird reserve by the Western Hemisphere Shorebird Reserve Network (WHSRN), a science-based, partnershipdriven, conservation initiative for the protection of the ecological integrity of critical habitats for shorebirds throughout the Americas. In 2018, the MMA proposed to expand the protection area of the Nature Sanctuary to 372 ha (Table 1). 
Table 1. Northern coastal wetlands and proposed environmental protection categories (BNP, National Protected Asset; MN, Natural Monument; PsCn Priority Sites for Conservation of Biodiversity; ShE Shorebird Reserve by WHSRN; SN, Nature Sanctuary; UW, Urban Wetland).

\begin{tabular}{|c|c|c|c|}
\hline $\begin{array}{c}\text { Region } \\
\text { Coastal Wetland Name }\end{array}$ & Year of Proposal & $\begin{array}{c}\text { Environmental } \\
\text { Protection Category }\end{array}$ & $\begin{array}{c}\text { Area to } \\
\text { Protect (ha) }\end{array}$ \\
\hline \multirow{4}{*}{$\begin{array}{c}\text { Arica Parinacota } \\
\text { Lluta river mouth ampliation }\end{array}$} & 2003 & PsCn & 175.22 \\
\hline & 2009 & SN & 30.64 \\
\hline & 2010 & ShE & 31 \\
\hline & 2018 (ampliation) & SN & 372 \\
\hline $\begin{array}{c}\text { Arica Parinacota } \\
\text { Camarones river mouth }\end{array}$ & 2020 & SN & 295 \\
\hline \multirow{3}{*}{$\begin{array}{l}\text { Antofagasta } \\
\text { Loa river mouth }\end{array}$} & 2005 & $\mathrm{BNP}$ & 508.3 \\
\hline & 2013 & $\mathrm{PsCn}$ & $10,856.9$ \\
\hline & 2019 & SN & 13,000 \\
\hline \multirow{2}{*}{$\begin{array}{l}\text { Antofagasta } \\
\text { La Chimba }\end{array}$} & 2021 & SN & \multirow{2}{*}{2.2} \\
\hline & 2021 & UW & \\
\hline $\begin{array}{l}\text { Atacama } \\
\text { Totoral }\end{array}$ & 2020 & $\mathrm{SN}$ & 368.7 \\
\hline $\begin{array}{c}\text { Atacama } \\
\text { Carrizal Bajo }\end{array}$ & 2019 & SN & 46.8 \\
\hline $\begin{array}{c}\text { Atacama } \\
\text { Copiapó river mouth }\end{array}$ & 2021 & $\mathrm{SN}$ & \\
\hline
\end{tabular}

\subsection{Camarones Wetland}

The Camarones river is exoreic, and it ends in the form of a very narrow gorge that gives origin to this narrow wetland of 689 ha (Figure 5B). The river mouth is located inside a rocky bay with a 1-km-long beach. Here, a small lagoon is formed, surrounded by a wetland fed mainly by groundwater and seawater infiltrations [62]. The hydrologic regime of the river is permanent with a mean annual discharge of $0.4 \mathrm{~m}^{3} / \mathrm{s}$ [63]. The water quality is poor with high salinity values and high boron and arsenic concentrations [64].

The most abundant vegetation comprises several species of reeds and totora. The current area is 689 ha, although its environmental conditions might be considered to be disturbed [4]. Two species of migratory birds have been traced in this coastal system. Hence, it does not represent an influential center of the concentration of avifauna, despite being used by 83 bird species [64]. This wetland has little relevance as an avian concentration site, yet it is part of the biological corridor needed to maintain the presence of birds in most key sectors [15]. The Camarones river mouth wetland was proposed as a Nature Sanctuary in 2020, protecting an area of 295 ha (Table 1).

\subsection{Loa River Wetland}

The Loa river is the longest and one of the most relevant ones in northern Chile. Its watershed covers an area close to $34,000 \mathrm{~km}^{2}$ and its length is $400 \mathrm{~km}$. Nevertheless, the river flows into the sea with very little water due to the intensive surface and groundwater exploitation, mainly concentrated in the middle sector of the fluvial valley. The current river discharge at the mouth is only $0.6 \mathrm{~m}^{3} / \mathrm{s}$, with minimum values of $0.07 \mathrm{~m}^{3} / \mathrm{s}$ [65]. The river presents a regime related to the altiplanic winter, determining the number of floods between January and March of each year [66]. 
In the Loa river mouth, a small coastal lagoon of 0.6 ha is formed, surrounded by a coastal wetland of 46.8 ha (Figure 5C), with very frequent submerged hydrophytes of shallow brackish water [67]. The increasing salinization of the river and the pollution derived from different industries, mining activities, and urban expansion upstream have led to an assembly mostly dominated by marine species [64]. Furthermore, this coastal wetland is used by 37 bird species, primarily seacoast birds, yet its current condition is only that of passage for several birds in transit. It is not representative of an outstanding location for wetland birds, but it does, however, correspond to a notable biological corridor between the highland/altiplanic plateau and the coast, as well as providing a resting place for migrating birds along the seaboard [15].

Since 2005, The Ministry of National Assets has been in charge of the conservation of the cultural and biodiversity patrimony of the Loa river mouth wetland [68], with the category of National Protected Asset (Table 1). This National Protected Asset allows the protection of the wetland formed by the meanders of the river around the mouth of the river, plus the conservation of the archaeological sites found in this fiscal property. In 2013, the Loa river mouth was declared a Priority Site of Conservation. In 2019 it was proposed to become a Nature Sanctuary, protecting an area of 13,000 ha.

\subsection{La Chimba Wetland}

La Chimba wetland has an area of approximately 2.21 ha and is located on the rocky coast of the city of Antofagasta (Figure 5D). It is characterized by the presence of azonal vegetation that is maintained owing to the groundwater supply from two coastal springs of a relatively constant flow regime. Both flow into the sea and connect the wetland with intertidal pools. The formation of small lagoons is used as a resting location for migratory and resident seabirds, as well as shelter for a high number of endemic and native species protected under different conservation categories, such as the Chimba snail (Heleobia chimbaensis). It is, therefore, an area of high diversity despite its small extension but is located in an urban and hyperarid area. In total, the catalogue of species includes three algae, 15 invertebrate, and 34 vertebrate (two fish, one reptile, 26 bird, and five mammal) species [69].

La Chimba wetland (2.2 ha) was declared a Nature Sanctuary in August 2021, and also an Urban Wetland by the MMA (Table 1). It will be the first urban wetland in northern Chile, protected by Law 21.202 [29] because of its high value as a landscape and habitat for endemic species. However, the municipality of Antofagasta should develop an ordinance for the conservation of this ecosystem and modify its regulatory plan by which land use is authorized as compatible with the protected area [29].

\subsection{Copiapó River Wetland}

Copiapó River watershed extends between $26^{\circ} 38^{\prime}$ and $28^{\circ} 38^{\prime} \mathrm{S}$, with a total area of $18,400 \mathrm{~km}^{2}$. Its mouth is located in the Copiapó Bay, forming a 60 ha lagoon surrounded by a sizable wetland of more than 345 ha, constituted by two subsystems (Figure 5E): (1) the river mouth; and (2) Las Salinas wetland, towards the north of the mouth and parallel to the foredune. At present, the Copiapó River is almost dry at its mouth all year around, and it is only during extreme hydrometeorological events that a noteworthy discharge reaches the wetland. Approximately $20 \mathrm{~km}$ upstream of the river mouth, a groundwater spring discharges the aquifer and allows a permanent flow of approximately $3.5 \mathrm{hm}^{3} /$ year. This supports the survival of the wetland [70], despite the exponential increase in the exploitation of the river-aquifer water resources since the 1980s and 1990s, mainly for agricultural and mining uses [71].

The discharge measurements for environmental monitoring from 2009 to 2011 [72,73] recorded maximum discharge values during the months of June and July, with values between 0.22 and $0.37 \mathrm{~m}^{3} / \mathrm{s}$. In general, from August/September an increase in evapotranspiration during these spring months is observed. The lowest discharge values are recorded during the austral summer months when the surface flow is almost non-existent. 
This hydrologic regime, accompanied by the seawater connection, regulate the existence and abundance of several species of macrophytes, with a total coverage of the wetland of $75 \%$ of its area. The wetland at the mouth of the Copiapó river is a prime focus of biodiversity concentration [17], since it is located in the northern edge of the distribution range of several species of the typical Mediterranean-type communities in Chile: 99 species of birds, 10 species of mammals, and six species of reptiles, highlighting the high number of endemic species. Regarding the flora configuration, according to the baseline studies and monitoring carried out at the mouth of the Copiapó River, 66 species and seven genera have been identified. The diverse vegetal associations inserted in the area provide a great diversity of food, shelter, and rest for the fauna and birds that constitute this avian assemblage.

In 2021 the MMA initiated the administrative process to propose the Copiapó River mouth wetland as a Nature Sanctuary. The northern sector of the Copiapó river mouth wetland is located in the terrestrial zone of the Multipurpose Coastal Marine Protected Area Punta Morro-Desembocadura río Copiapó-Isla Grande de Atacama [74], so it is expected that by protecting the Copiapó River mouth wetland, both protected areas will complement future actions to achieve the conservation of these notable coastal ecosystems (Table 1). They are representative of systems of global and regional importance and contain the distinguishing habitats of the coastal upwelling system of the Humboldt current and the subtidal and intertidal environments of northern Chile.

\subsection{Totoral and Carrizal Bajo Wetland}

The Totoral and Carrizal Bajo coastal wetlands are located on the southern edge of both the Atacama Desert and the study area, where the climate varies from hyperarid to arid conditions. They are approached together here, in the same section, since both have similar features, are exposed to analogous threats, and are located only $28 \mathrm{~km}$ apart. These wetlands' main peculiarity is their microhabitat diversity.

The Totoral coastal wetland covers an approximate area of 368.7 ha (Figure 5F) and connects with Totoral ravine, which is generally dry except during extreme hydrometeorological events that occur upstream. Most of the time, surface water is limited to three small lagoons at the mouth of the stream and only $60 \mathrm{~m}$ away from the coastline between 3 and 8 $\mathrm{m}$ a.s.l. These lagoons are mainly fed by groundwater, allowing the existence of flora and fauna. The connection between these and the sea only occurs during either marine (storms and tsunamis) or continental (floods) extreme events. Near the mouth, the detrital aquifer is 30 to $40 \mathrm{~m}$ thick and the water table is $\sim 2 \mathrm{~m}$ a.s.l. without seasonal variations [75,76]. A floristic richness of 112 species has been verified, with $40 \%$ being endemic species that include distinctive species of both the desert bloom and cacti. A total of 72 species of vertebrate fauna have been identified: 58 birds (nine migratory species), three reptiles, and 11 mammals [75].

The Carrizal Bajo coastal wetland involves an area of 56.6 ha and it is formed by a narrow lagoon, about $60 \mathrm{~m}$ wide and $600 \mathrm{~m}$ long, that occupies the mouth of the Carrizal Bajo ravine, orientated NNW-SSE (Figure 5G). This lagoon is surrounded by low salty vegetation that extends more than $1 \mathrm{~km}$ landwards, where it starts to show evidence of water stress. The lagoon is separated from the sea by a littoral sandy beach that occasionally, during extreme hydrometeorological events, is eroded. The wetland and the lagoon are fed by both marine and ground waters. This wetland-lagoon system is a rich coastal ecosystem, distinguished by its rich biodiversity. The flora and fauna are diverse, and a total of 51 plants and 76 bird species have been identified, including batrachians, reptiles, mammals, and fishes [77]. Hydrophilic vegetation such as Juncus acutus, Distichlis spicata, Salicornia peruviana, and Alstromeria spp. are frequent. Landwards, this vegetation is substituted by halophytic vegetation, adapted to salty soils and water scarcity. This coastal wetland is one of the most relevant and carefully preserved in the Atacama Desert [78].

The creation of the Totoral Coastal Wetland Nature Sanctuary was approved at the end of 2020 and the status is awaiting presidential signature and publication in the Official Jour- 
nal (Table 1). In August 2020, the creation of the Carrizal Bajo Wetland Nature Sanctuary was approved [79], recognized as a hotspot of global importance for its biodiversity, with an approximate surface area of $46.8 \mathrm{ha}$. It is located within the Priority Site of Conservation called the "Huasco and Carrizal River Estuary". The Carrizal Bajo wetland is located very close to the Llanos de Challe National Park (3.5 km away), so complementary conservation actions could be promoted.

\section{Main Threats to Chilean Coastal Northern Wetlands}

\subsection{Natural Threats}

\subsubsection{Large Megathrust Earthquakes}

On the coast of Chile, large megathrust earthquakes ( $\mathrm{Mw}>8)$ may cause the significant tectonic uplift of some coastal segments, generating important modifications to the benthic community of the wetlands [80]. The uplift process causes the coastal wetlands to perch above the sea level, reducing the marine intrusion and causing adjustments in the species distribution: species tolerant to the new less-brackish conditions will increase in abundance, whereas intolerant ones will disappear. In addition, desiccation and decomposition of organic matter could result in drastic physical-chemical-biological transformations of these systems [43]. Other authors [81] who have described significant coseismal uplifts of wetlands in Chile indicate that this led to the total drying up of the internal channel network that irrigates the coast, which would be even more pronounced in the arid wetlands. This also limited the water exchange with the sea, generating a decrease in the salinity of the waters towards the interior of the wetland. The desiccation of a considerable part of the wetland's bottom led to the mortality of benthic invertebrates that inhabited them, whereas the extensive saline pastures did not show signs of being affected. These large megathrust earthquakes also trigger large tsunamis that cause profound shifts in these coastal systems, including not only geomorphological modifications but also variations in their physical, chemical, and ecosystem characteristics.

\subsubsection{Marine High-Energy Events}

Marine high-energy events, storms and tsunamis, are the most common natural threat that may cause damage to the coastal wetlands of northern Chile. Currently, this zone is highly coupled and can be considered mature for high-magnitude tsunamigenic earthquakes for the next years ( $\mathrm{Mw}>$ 8.5) [37]. Likewise, the projections of the significant wave height of storms indicate potential increases for the coming decades [35]. Both processes will be aggravated by the sea-level rise that is expected for the next decades $(0.6 \pm 0.10 \mathrm{~m}$ a.s.l.), which will facilitate the extent of the waves' horizontal flood landwards, eroding the coastal dunes and beaches and increasing the salt concentration in surface and groundwaters [6]. All these will cause damage in wetland ecosystems and in coastal morphology, more notably close to the shoreline, and will modify the dynamics of the coastal processes and plant communities that play a fundamental role in these processes, such as sediment stabilization and tidal control [82]. However, coseismic uplift, which has been continuous since the Late Pleistocene in the study area [83,84], has a byproduct related to the mitigation of sea level rise on Chilean coasts.

The most destructive high-energy marine events reported in the northern sector of the study area $\left(18^{\circ}-21^{\circ} \mathrm{S}\right)$ were the 1868 and 1877 tsunamis of Arica and Iquique (Mw 8.8). These events may have generated severe damage in the Lluta, Camarones, and Loa coastal wetlands. There are not chronicles or historical studies that report the geomorphic and ecosystemic shifts on this coastal sector, although the run-up was close to $12 \mathrm{~m}$ in the 1868 tsunami event and between 5 and $19.75 \mathrm{~m}$ in the 1877 one [85]. Similarly, the most recent and moderate 2014 event $(\mathrm{Mw} \sim 8.2)$ might have caused some harm in these environments [39]. Specifically, the largest runup along the northern Chilean coast during the marine flooding associated with the 2014 tsunami was measured in Camarones wetland $(4.63 \mathrm{~m})$, with a very short inundation distance [86]. Even though no damages have been recounted after extensive storm events, the extreme storm episodes of 1924, 1983, 1985, and 
1987, with wave heights between 3 and $8 \mathrm{~m}$ gather the features to develop broad overwash and some losses in the Lluta, Camarones, and Loa coastal wetlands [33].

In the southern sector of the study area, the La Chimba wetland is located between 3 and $10 \mathrm{~m}$ a.s.l. and as a result, it may well be affected by tsunami events with runups close to those heights (e.g., 1868, 1877, and 1922 events) [39]. Copiapó, Totoral, and Carrizal Bajo wetlands were also probably affected to some extent by these large events. The tsunamigenic event with the highest magnitude chronicled for this southern sector was identified by Abad et al. [40] (Mw 8.8-9.4) and dated to 1420 CE. This event caused a tsunami flood depth of $18.5 \mathrm{~m}$ a.s.l. and wave heights of probably up to $24 \mathrm{~m}$ near Cisne Bay, only $8 \mathrm{~km}$ north of the Copiapó wetland. This catastrophic event must have caused a dramatic alteration in the littoral landscape of the southern Atacama Desert. Likewise, the 1922 historic tsunamigenic event $(\mathrm{Mw}$ 8.6), with tsunami heights of $8 \mathrm{~m}$ a.s.l. near Caldera, severely affected this sector ([40] and reference therein). Although no chronicles exist for Copiapó and Totoral wetlands for this tsunami event, significant impacts are described for Carrizal Bajo. Here, the sea flooded the ravine mouth, penetrating more than $2 \mathrm{~km}$ landward [87], washing away the port and railway infrastructures. The run-up was estimated to be $2 \mathrm{~m}$ a.s.l. Moreover, Forch [88] has recently illustrated the geomorphologic record of the 1922 event in this wetland. An erosive scarp can be identified at the edge of the lagoon as evidence of the erosion caused by these tsunami waves. Forch proposed that the coastal lagoon was formed via the effect of erosion on the ravine during the tsunami backwash. Indeed, the transoceanic tsunami that occurred in 2011, triggered by the Tohoku earthquake (Mw 8.3), caused the inundation of the Copiapó wetland and the deposition of a sand layer near the shoreline plus the erosion of the beach and the foredune. Nevertheless, these processes did not imply a remarkable transformation for the wetland geomorphology and ecosystem ([89] and references therein). The 2011 Japanese tsunami also affected the Carrizal Bajo wetland, where the flood reached $1 \mathrm{~km}$ landward and the backwash erosion of the littoral sand barrier emptied the water lagoon over the course of weeks [88]. On the other hand, as it occurs in the northern sector of the study area, the effect of storms is poorly studied and there is no literature focused on their impact in wetlands. Because of its proximity to the sea-level, the La Chimba wetland can be affected by extreme storms with considerable wave heights, similar to those reported for Antofagasta in the years 1924, 1929, 1965, 1983, 1997, 2003, 2006, 2011, 2013, and 2015. Similarly, Copiapó, Totoral, and Carrizal Bajo wetlands could have been affected near the shoreline by the extreme storms of 1993, 1997, and 2015 [33].

As mentioned, little is known about the impact of marine high-energy events in northern Chile's coastal wetlands. Nonetheless, many studies have focused on the damages caused by recent tsunamis in littoral systems and coastal wetlands worldwide, and some of them have focused on central-southern Chile [90-93]. All these authors highlight the exceptional morphological alterations suffered after the impact of large tsunamis that prompted substantial alterations in the physico-chemical and biological patterns of the system, usually caused by the extensive connection of the estuary with the ocean after the tsunami impact [94]. They also note a relatively quick recovery of the coast to a pre-tsunami state. Specifically, the Indian Ocean tsunami of 2004 illustrated the physical destructive potential of these events on coastal wetlands at a large spatial scale. An assessment by Indonesia's State Ministry of National Development Planning estimated that 25-35\% of coastal wetlands were destroyed in the tsunami-affected areas [95]. Furthermore, severe damage was observed in the Nicobar Islands coastal ecosystems after this event [96], where an integrated coastal zone management plan was proposed to restore the coastal ecology that included removal of mud and silt from shallow marine areas, the removal of debris and other materials from beaches and wetland areas, and afforestation of deforested areas. Additionally, the 2011 Tohoku-oki tsunami carried a heavy load of sediment, nutrient, and salinity up to $5 \mathrm{~km}$ inland on the Sendai plain [97]. The affected freshwater wetlands became saline or brackish and remained at highly elevated salinity levels for up to five months. Even after surface water salinity decreased, salt concentrations in the soils remained 
elevated in some areas for almost a year. Moreover, coastal ecosystems seem to respond and recover in different ways to tsunami wave flooding. For example, after the Illapel 2015-Mw 8.4-earthquake in central Chile, several semiarid wetlands in the Coquimbo Bay showed high resilience to the impact of the triggered high-energy marine event [98] as no significant differences were observed in the vegetation structure and water-bird richness before and after the event.

The effects of storms on coastal wetlands are comparatively more intensively studied. Storms affect coastal wetland eco-geomorphology in a variety of ways and at different scales [99]. From a physical and geomorphic perspective, winds and waves lead to the movement of barrier islands, the erosion of upland and wetland edges, and to the blowdown of wetland trees [100]. As in the case of tsunamis, several works highlight saltwater intrusion as one of the most damaging long-term effects on these natural systems [101]. Vegetation in freshwater and brackish wetlands is not adapted to the high-salinity waterassociated surge and therefore dies, leaving bare soil that is vulnerable to erosion. After inundation, wetland recovery depends on several factors, including post-intrusion salinity and the flooding level [102]. If saline water is trapped inland by levees or roads, recovery can be extremely slow. Finally, recent works have focused on the impact of typhoons and hurricanes on coastal wetland ecosystems [103], describing the loss of foliage, broken trunks, and even uprooting. These extreme high-energy marine events also affect large aquatic plants and phytoplankton, such as seagrass and algae, involving their community structure and species richness. The numbers of coastal wetland animals and their species diversity commonly decrease.

It must be considered whether all the coastal wetlands in the study area are highly threatened by marine high-energy events and exposed to their impacts. Storms are a low-to-medium threat to these systems at these latitudes of the Chilean coast (Table 2), with much higher significant wave heights south of the study area. Nonetheless, they may still cause some impacts related with marine water intrusion by the storm surge and the erosion of littoral spits, beaches, and foredunes. Tsunamis, in contrast, are a more serious threat to all the studied coastal wetlands except for La Chimba, which is located in a rocky cliff several meters above the sea level, with some protection against the waves. Water and soil salinization and the soil loss caused by erosion are especially noteworthy, considering that freshwater and sediment input is extremely low. The reasons for this are the (hyper-)arid characteristics of these systems and the anthropic (over)exploitation of water resources for agriculture and mining upstream in most of the cases (Table 2). In addition, these (hyper)arid fluvial basins show strong seasonality in terms of runoff. Consequently, future climate scenarios are highly uncertain in terms of annual precipitation modifications. Indeed, it is also unclear whether total runoff volume will increase or decrease, although a reduction is expected $[104,105]$. Certainly, it is imperative to contemplate that although most research highlights the resilience and fast recovery (months to years) of both the abiotic environment and the ecosystem services of these coastal wetlands, none of these studies has analyzed arid wetlands under anthropic pressure, i.e., much more fragile systems. 
Table 2. Main natural and human threats to the arid coastal wetlands of northern Chile. Abbreviations of the wetland names are explained in Figure 3. Threats: SCL, sea-level change; TSU/CU, tsunami and coastal uplift; STO, storms; FFL, flash flood; WP, water pollution; WE; water extraction (surface and groundwater); WS, watershed (dammed); SC, soil contamination; FD, farming; PI, polluting industry; WF, wildfire; UD, urban development; TV, traffic of vehicles; WD, waste dump; WLP, wildlife perturbation and poaching; IS, invasive species. Dark, medium, and light gray colors indicate the different hazard grades, from high to low respectively.

\begin{tabular}{|c|c|c|c|c|c|c|c|c|c|c|c|c|c|c|c|c|}
\hline & \multicolumn{4}{|c|}{ Natural Threats } & \multicolumn{12}{|c|}{ Anthropogenic Threats } \\
\hline & SLC & TSU/CU & STO & FFL & WP & WE & WS & SC & FD & PI & WF & UD & TV & & VDWLP & IS \\
\hline LLU & & & & & $X$ & & & $X$ & & & $X$ & $X$ & $X$ & & $X$ & \\
\hline CAM & & & & & $X$ & & $X$ & $X$ & $X$ & & & & & $X$ & $X$ & $X$ \\
\hline LOA & & & & & $x$ & $X$ & $X$ & & & $X$ & & & & & & \\
\hline CHI & & & & & $X$ & $X$ & & & & & & $X$ & & $X$ & $X$ & $x$ \\
\hline COP & & & & & $X$ & $X$ & $X$ & & & & $X$ & $X$ & $X$ & $X$ & $X$ & $x$ \\
\hline TOT & & & & & & $X$ & & & & & & & $X$ & & $X$ & \\
\hline CAR & & & & & & $X$ & $X$ & & & & $X$ & $X$ & $X$ & $X$ & $X$ & \\
\hline
\end{tabular}

\subsubsection{Hydrometeorological Extreme Events}

River flooding is a growing problem in coastal areas in Chile due to the profound environmental transformations that have taken place since the mid-20th century. This phenomenon is being aggravated by climate change, which is helping to increase their frequency and/or magnitude [106]. In the Atacama Desert, the hydrometeorological extreme events and floods are the other most frequent natural processes that periodically threaten coastal wetlands. They are normally caused by lows that occurred mainly during the austral summer and with a frequency related with ENSO events in the Pacific Ocean [107-112]. These events have been frequently recorded in all the studied wetlands located in the mouths of fluvial valleys.

In the northern sector of the study area, with an IDM $<0.25$, the Lluta river mouth and its wetland have experienced several floods during the last decades, notably those occurring in 1911, 2001, 2004, and 2005, with the last two recording discharges of 3.1 and $7.7 \mathrm{~m}^{3} / \mathrm{s}$ respectively. Unfortunately, their geomorphologic impact has not been studied apart from those related with losses in the agricultural fields and the copious amounts of sediment load discharged to the sea [113]. Similar circumstances occur in Camarones, where historical and recent evidence exists of floods along the fluvial valley, although no work has yet been focused on the study of their effects in its mouth. Lastly, Ortlieb [114] describes an extensive flood in the Loa River in 1884, with catastrophic consequences throughout the valley that reached its mouth and coastal wetland, causing a remarkable transformation in its geomorphological configuration.

By contrast, in the southern sector of the study area, with IDM between 0.25 and 0.5 , river flooding is more frequent and often has catastrophic consequences, specifically in the Copiapó river valley $[110,114,115]$. In this sense, its coastal wetland has recently experienced two extreme flood events in 2015 and 2017 that generated major geomorphological transformations such as the channel widening, the deposition of sands and muds in a vast area of the wetland, and the infilling of ponds and lagoons with muddy sediments [109]. During both events, the system showed a rapid recovery, and a hydraulic reconnection between the marine water and the coastal lagoon was recorded. Other historical events that may have caused damage in these wetlands occurred in 1888 and 1997 [114]. For the Totoral and Carrizal wetlands, no descriptions have been made of the impact of these extreme events, although interviews with locals have explained that massive fine sediment was discharged during these events, partially infilling the lagoon and bay of Carrizal Bajo over several weeks.

Catastrophic continental floods affect the studied coastal wetlands to different degrees, depending on the extent of their watershed (Table 2). When they include the Andes Range in the upper part of the basin, large and highly energetic discharges occur after extreme 
hydro-meteorological events, commonly related to the ENSO $[107,111,112]$. The impact of this process in coastal wetlands is insufficiently studied in Chile, even though the sudden supply of massive quantities of water and sediments generates marked variations in their geomorphology. In this sense, Totoral and Carrizal Bajo are the least threatened wetlands due to their smaller watersheds, as is La Chimba with its origin in a coastal spring. Some of the expected transformations include the deposit of up to $50 \mathrm{~cm}$ of silts and sands, the partial or complete filling of lagoons and ponds, the erosion and widening of the channels, the dragging of the vegetation, and the rupture of littoral spits and foredunes that close the estuaries $[89,109]$. Climate change projections for the highest greenhouse gas emission scenario point to a decrease of up to $30 \%$ in the annual precipitation in the study area towards the end of the 21st century [104]. However, superimposed on this climate scenario, some authors $[110,116]$ suggest that stronger rainfall events modulated by ENSO and ENSO-like conditions will also affect the southern sector of the study area. This suggested trend in ENSO events was recently identified by Freund et al. [117] after reviewing the past four centuries of El Niño variability. The authors found that the most recent 30-year period included fewer, but more intense, Eastern Pacific El Niño events, such as the 2015/2016 event, one of the strongest in the past 400 years, related to the March 2015 catastrophic floods in Atacama [46,111,118]. This damaging scenario, with fewer but more intense events, may therefore lead to a decrease in the total number of floods associated with an increase in high-magnitude floods during the next decades that will have higher impacts on the coastal wetlands located at the mouths of these arid rivers.

\subsection{Anthropogenic Threats}

There are multiple human stressors in coastal wetlands, as reviewed by Ostroski et al. [119], but particularly in the coastal wetlands of northern Chile, the most disturbing human activities are agriculture, mining, tourism, aquaculture and fishing, overexploitation of water resources, water pollution, informal settlements (locally known as "tomas"), and wildfires, among many others related to uncontrolled tourism [120]. Moreover, it is common to observe cattle grazing and the disturbance of shorebirds by feral dogs that alter biodiversity behaviors [82]. Some of the studied wetlands are relatively far from urban centers, which are uncommon along these coasts (Figure 1). Thus, the main anthropogenic threats to the wetlands do not necessarily come directly from the large coastal urban centers, but rather from human activities in sectors located upstream. In general, the rivers of northern Chile show poor water quality, which limits their uses [15]. Although present Chilean regulations do not allow untreated mine tailings to be directly discharged into the fluvial and coastal environment [121], the persistent impacts of copper pollution from former historical discharges and current illegal procedures have caused strong negative effects $[122,123]$.

The Lluta river wetland is threatened by the urban growth of the city of Arica along with the exploitation of water resources for human consumption and agriculture [15]. Fertilizer runoffs from the numerous agricultural fields located in wetland surroundings affect the quality of the waters of the Lluta river, characterized by a high concentration of boron that increases along the course of the river [113]. These high levels of B reduce the agricultural productivity and the variety of species that can be cultivated within the valley. In addition, Copaja and Muñoz [124] detected high levels of $\mathrm{Cu}, \mathrm{Fe}, \mathrm{Mn}, \mathrm{Zn}$, and $\mathrm{Al}$ in the sediments of the river mouth. Moreover, a coastal road gives access to the area for recreation activities with the consequent frequent transit of vehicles in the area, as well as feral dogs that disturb the fauna that live in and visit the wetland [4]. Other threats include aggregate extraction and the occurrence of dumping sites. Finally, the local media reported wildfires that affected several hectares of the wetland in 2008 and 2019, without important consequences [125].

Much of the lower course of the Camarones river has been modified by agricultural activities and facilities, although its greatest threat is water exploitation along the watershed and in the wetland, where it is also affected by the presence of a chicken farm $[4,15]$. Other 
anthropogenic threats have minor impacts, such as the existence of several illegal dumpsites and the presence of feral dogs and invasive species [63].

On the other hand, the Loa river and its coastal wetland has high bacterial and chemical pollution due to the increasing salinization of the river and the pollution derived from different industries and the urbanization upstream [15]. Moreover, this fluvial system is mainly impacted in its upper part where water extraction occurs for mining uses. Because of this, water is scarce and is of low quality at its lower sector. A sizable episode of contamination occurred in 1997, from which the system has not yet recovered, with xanthates, isopropanol, detergents, and heavy metals, causing the massive death of shrimps and fish, among other groups. Subsequently, the wetland surroundings were highly modified by fishing and industrial activities [4].

Regardless of the small size of the area, the La Chimba urban wetland is exposed to numerous threats due to its location inside the urban limits of Antofagasta. Its conservation depends completely on groundwater as it was formed by a coastal spring and thus any intervention/pollution in the aquifer may have a profound negative impact on this unique ecosystem. The most frequent threats are solid waste dumping, feral dogs and cats that hunt wildlife, and the introduction of exotic and invasive species in the wetland [69].

Copiapó wetland hydrology is highly influenced by the intense overexploitation of the aquifer in the upper watershed for mining and agricultural uses [71]. The low surface water discharge that reaches the river mouth has considerably reduced the effective channel section that is now colonized by macrophyte vegetation that increases the impact of floods during extreme events. In addition, even under favorable hydric conditions, the wetland extension is restricted by the surrounding roads and bridges [72]. On the other hand, technical reports [73] point out that the wetland water presents high nutrient concentrations of $\mathrm{N}$ and $\mathrm{P}$, with a probable origin in diffuse sources from the agricultural fields upstream. This eutrophication generates overdeveloped vegetation that consumes appreciable quantities of oxygen, resulting in an increase in the metal content in the wetland sediments and water. Furthermore, the presence of tourists that camp and dispose of waste is frequent, as well as the circulation of vehicles inside and in the surroundings of the wetland. The presence of feral dogs is also a serious threat to wildlife in this wetland [4]. Finally, two wildfires that affected 17 ha occurred during the summer of 2009 after a long drought period [72,73].

The Totoral wetland is highly threatened by the direct exploitation of the lagoon water and the aquifer that feds it by wells located nearby and upstream for agricultural and domestic purposes $[75,76]$. Other threats impacting this wetland include poaching, arid extraction, illegal urbanization, sheepherding and stray dogs, and the existence of roads and paths that fragment the wetland and the natural waterways. In contrast, the main threats to the Carrizal Bajo wetland are water pollution, since eutrophication events have caused episodes of massive death of the wetland's ichthyofauna in recent years, as well as groundwater extraction occurring upstream. Other increasing threats to the Carrizal Bajo wetland are unregulated tourism, urban expansion, illegal poaching, the circulation of off-road vehicles, and small dumping sites, including the dumping of solid residues into the lagoon. This wetland suffered a wildfire in 2018 that burned 4 ha and produced severe damage to the halophyte plant communities, mainly formed of Sarcocornia fruticosa and Distichlis spicata [78].

\section{Discussion}

Dryland coastal wetlands, such as those studied here, are of key importance for regional ecological resilience and are particularly vulnerable due to their dependence on a fragile hydro(geo)logical equilibrium. As explained, the coastal areas of northern Chile are exposed to a wide variety of processes, both natural and anthropogenic, which are considered to be change triggers for the wetland ecosystems (Table 2). Among the different anthropogenic threats that may affect wetlands, twelve have been identified in the studied coastal ecosystems. The most threatened wetlands are Copiapó, with nine 
identified threats; Carrizal Bajo and Camarones, with seven; and La Chimba and Lluta, with six (Table 2). In all of them, uncontrolled tourism occurs with consequent wildlife perturbation and the occurrence of illegal dumping sites and/or wildfires. Furthermore, the exploitation of surface and groundwater resources next to and upstream of the wetlands is the most hazardous threat, as these ecosystems occur because of the input of freshwater, either surface water or groundwater, that governs the suitability of local conditions for specific wetland species [126]. The conservation of the wetland vegetation depends directly on the supply of water, and this vegetation offers food, shelter, and rest for wildlife and birds. Therefore, a minimum flow rate must be ensured to guarantee the survival of these ecosystems. Moreover, the core of the diversity in wetlands is the lagoons, as these are hotspot of the richness and abundance of birds. Therefore, its protection is fundamental to preserve the biodiversity of these ecosystems. Undeniably, it is vital to incorporate the adjacent sectors, such as beaches, slopes, and marshes, as buffering areas to avoid human pressures (in these cases, illegal human installations, dune interruptions, and other disturbances such as cars, dogs, etc.). This would ensure the protection of the ecosystem and thus of endemic and vulnerable species. Moreover, these systems are particularly sensitive to natural threats that include coastal uplift, marine high-energy events, and continental floods, the latter of which are affected by the current climate changes.

Wetland protection categories do not normally contemplate mitigation plans against the described natural threats; however, the "healthier" the wetland is, the more resilient it will be to their impacts. The health status is related with the human pressure they suffer and the anthropogenic threats they are exposed to. The environmental management of these complex and vulnerable coastal systems, that develop in very particular geomorphologic and climatic contexts, has been rarely approached in the scientific literature during recent years $[14,127]$. These works highlight the importance of a deeper understanding of the functioning of arid wetlands and the enforcement of legislative frameworks that protect both life and fresh water sources, as well as conservation management in order to assess the exent of short- and long-term impacts.

The coastal wetlands of northern Chile are especially vulnerable despite their rich biodiversity, the presence of endemic species, and their role as buffer areas in the case of tsunamis and/or floods, among others. Their heterogeneous distribution and the distance among them (e.g., there is around $247 \mathrm{~km}$ between the consecutive wetlands of Camarones and the Loa river mouth) implies that bird migratory routes will be interrupted in the case of severe degradation or damage in any of these areas. Protection categories should be addressed to protect the environmental structure (physical environment, flora and fauna, ecological relations, etc.) and to preserve these ecosystems. Furthermore, wetlands act as carbon sinks against climate change so their protection and promotion would help to achieve Chile's carbon neutrality goals by 2050 (Paris Agreement, COP21). All the studied coastal wetlands are protected by at least one environmental category (most of them very recently or still in the proposal stage); only La Chimba and Lluta are protected by more than one (Table 1). Nevertheless, these categories do not consider the integrated management of the hydrologic system that includes the middle and upper sectors of the basins. For example, the Marine Protected Area (MPA) category that protects the Copiapó wetland only includes the northern sector, leaving the southern half of the wetland unprotected, and it does not include any measurement related with the preservation of a minimum ecological discharge value feeding the ecosystem. Additionally, the Urban Wetland category (Law 21.202) does not prevent urban environments around wetlands from altering sedimentation and hydrological regime systems [128,129].

Regarding legal instruments and administration tools affecting wetlands, there is a notable segmentation of powers among the different institutions. There are competences established in several regulations that overlap with each other and with differing legal motivations. This makes it difficult for the different public institutions to act in a coordinated and systematic way. Therefore, policies and management plans should be oriented towards the accomplishment of the international categories' requirements, such as those of 
Ramsar sites. Likewise, there is an obvious fragmentation between the private and public sector and the community. More specifically, the public sector displays little inter-sectorial coordination of wetland monitoring and little knowledge of the functionality and integrity of variables of the ecological state of these areas. The community requires greater sensitivity and environmental training, and the private sector has implemented few wetland mitigation and restoration measures. Infrastructure, wetland management, and official protection plans are required, but these should be adapted to the inherent characteristics of the arid coastal wetlands of northern Chile.

\section{Conclusions}

There is an unequal distribution of wetlands across the Chilean territory, and this is especially notable in the northern regions, where the disconnection between coastal wetlands affects them in terms of vulnerability. In addition, the coastal wetlands of northern Chile are exposed to a wide variety of threats, both natural and anthropogenic, which makes them particularly fragile and vulnerable due to their development in a (hyper)arid environment such as that of the coastal Atacama Desert. This requires a deeper scientific understanding of the functioning of these ecosystems, which is still missing for these arid coastal wetlands.

There is also a lack of management tools and there is mismanagement of coastal wetlands in northern Chile. The convergence of many institutions with different competences leaves some aspects uncovered and some functions uncoordinated, such as regulatory inspections. Hence, the scarcity of categories that protect these coastal wetlands, and the failure of these categories to consider the particularities of arid wetlands, makes them especially vulnerable. These dryland coastal wetlands should be preserved not only because of their uniqueness but also for the ecosystemic services they provide.

The integrated management of both natural and anthropogenic threats and their catastrophic consequences in littoral regions requires a multidimensional approach-involving ecological, geological, and socioeconomic elements-towards the protection and conservation of coastal wetlands. It is essential to enact a coastal law in Chile that will make it possible to confront climate change in coastal ecosystems where there are no integrated protection regulations. This new coastal law should modify the concept of the coastal edge to a coastal zone, which would mean protecting more territory. The coastal edge comprises $80 \mathrm{~m}$ from the highest tidal line, whereas the coastal zone would allow the protection of several kilometres inland, including coastal ecosystems such as wetlands, dune fields, and beaches.

Supplementary Materials: The following are available online at https:/ /www.mdpi.com/article/10 $.3390 / \mathrm{jmse} 9090948 / \mathrm{s} 1$, Table S1: Regulatory and institutional framework with competences in the coastal zone, as well as its management and planning instruments.

Author Contributions: Conceptualization, N.N. and M.A.; methodology, N.N., M.A., E.B. and T.I.; investigation, N.N., M.A., E.B. and T.I.; writing—original draft preparation, N.N., M.A., E.B. and T.I.; writing-review and editing, N.N., M.A., E.B. and T.I.; visualization, N.N., M.A., E.B. and T.I. All authors have read and agreed to the published version of the manuscript.

Funding: This work is a contribution to the ANID/CONICYT/FONDECYT 11180015 project and to the DIUDA Project No 22365 (Insertion Program) of the Atacama University.

Data Availability Statement: Not applicable.

Conflicts of Interest: The authors declare no conflict of interest.

\section{References}

1. UNESCO. Convention on Wetlands of International Importance Especially as Waterfowl Habitat. Ramsar, Iran, 2.2.1971 as Amended by the Paris Protocol of 3.12.1982 and the Regina Amendments of 28.5.1987; United Nations Educational, Scientific and Cultural Organization (UNESCO): Paris, France, 1982. 
2. Oyarzun, E.S. Ecosystem services affected by natural disasters at coast and sea. In La Zona Costera en Chile: Adaptacion y Planificacion Para la Resiliencia; Hidalgo, R., Martinez, C., Henriquez, C., Arenas, F., Rangel-Buitrago, N., Contreras-Lopez, M., Eds.; Instituto de Geografía-Serie GEOlibros: Santiago, Chile, 2019; pp. 285-307.

3. Myers, N. The biodiversity challenge: Expanded hot-spots analysis. Environmentalist 1990, 10, 243-256. [CrossRef] [PubMed]

4. Tabilo, E.J.; Burmeister, C.; Chávez, C.; Zöckler, C. Humedales y Aves Migratorias en la Costa Árida del Pacífico Sudamericano; Etapa 1; Unpublished Technical Report; Centro Neotropical de Entrenamiento en Humedales y Manfred Hermsen Stiftung: Coquimbo, Chile, 2016; p. 93.

5. Peña-Cortes, F.; Pincheira-Ulbrich, J.; Fernandez-Soto, E.; Rebolledo, G.; Andrade, E.; Salinas, C. Land use planning in Chile: Challenges to incorporate the integrated management of coastal zones. In La Zona Costera en Chile: Adaptacion y Planificacion Para la Resiliencia; Hidalgo, R., Martinez, C., Henriquez, C., Arenas, F., Rangel-Buitrago, N., Contreras-Lopez, M., Eds.; Instituto de Geografía-Serie GEOlibros: Santiago, Chile, 2019; pp. 353-376.

6. Thorne, K.; MacDonald, G.; Guntenspergen, G.; Ambrose, R.; Buffington, K.; Dugger, B.; Freeman, C.; Janousek, C.; Brown, L.; Rosencranz, J.; et al. Pacific coastal wetland resilience and vulnerability to sea-level rise. Sci. Adv. 2018, 4, eaao3270. [CrossRef] [PubMed]

7. Barragán, J.M.; Castro, C.; Alvarado, C. Towards Integrated Coastal Zone Management in Chile. Coast. Manag. 2005, 33, 1-24. [CrossRef]

8. Bortolus, A.; Schwindt, E.; Bouza, P.J.; Idaszkin, Y.L. A characterization of Patagonian Salt Marshes. Wetlands 2009, 29, 772-780. [CrossRef]

9. Alvarez, M.P.; Carol, E.; Dapeña, C. The role of evapotranspiration in the groundwater hydrochemistry of an arid coastal wetland (Península Valdés, Argentina). Sci. Total Environ. 2015, 506-507, 299-307. [CrossRef]

10. Saintilan, N.; Rogers, K.; Kelleway, J.J.; Ens, E.; Sloane, D.R. Climate Change Impacts on the Coastal Wetlands of Australia. Wetlands 2019, 39, 1145-1154. [CrossRef]

11. Curreli, A.; Wallace, H.; Freeman, C.; Hollingham, M.; Stratford, C.; Johnson, H.; Jones, L. Eco-hydrological requirements of dune slack vegetation and the implications of climate change. Sci. Total Environ. 2013, 443, 910-919. [CrossRef]

12. Carling, G.T.; Richards, D.C.; Hoven, H.; Miller, T.; Fernandez, D.P.; Rudd, A.; Pazmino, E.; Johnson, W.P. Relationships of surface water, pore water, and sediment chemistry in wetlands adjacent to Great Salt Lake, Utah, and potential impacts on plant community health. Sci. Total Environ. 2013, 443, 798-811. [CrossRef]

13. Firouz, E. Wetland Conservation and Management Problems. In EARTHCARE: Global Protection of Natural Areas; Schofield, E.A., Ed.; Routledge: New York, NY, USA, 1978; pp. 235-245. [CrossRef]

14. El Hadji, S.; Thiaw, I.; Birguy, L.D. Managing Wetlands in Arid Regions: Lessons Learned; IUCN: Gland, Switzerland; Cambridge, UK, 2006; p. 82.

15. Sielfeld, W.; Peredo, R.; Fuentes, R.; Malinarich, V.; Olivares, F. Coastal Wetlands of Northern Chile. In The Ecology and Natural History of Chilean Saltmarshes; Fariña, J.M., Camaño, A., Eds.; Springer: Cham, Switzerland, 2017; pp. 105-168.

16. Cortez, M. Andes Copper Company y CODELCO destruyen el río Salado y la Bahía de Chañaral. In Conflictos por el Agua en Chile: Entre Los Derechos Humanos y Las Reglas del Mercado; Larraín, S., Poo, D., Eds.; Gráfica Andes: Santiago, Chile, 2010; pp. 128-139.

17. MMA (Ministerio del Medio Ambiente). National Inventory of Wetlands. 2020. Available online: https://humedaleschile.mma. gob.cl/ (accessed on 15 December 2020).

18. Castro, C.; Alvarado, C. La gestión del litoral chileno: Un diagnóstico. In Manejo Costero Integrado y Politica Publica: Un Diagnostico. Necesidad de Cambio; Barragán Muñoz, J.M., Ed.; Universidad de Cádiz: Cádiz, Spain, 2010; pp. 211-234.

19. Barragán, J.M. Gestión de las Áreas Litorales en España y Latinoamérica; Universidad de Cádiz (UCA): Cádiz, Spain, 2005.

20. Andrade, B. Los Espacios Litorales: Definiciones, Actores, Desafíos y Perspectivas. In Ordenamiento del Territorio en Chile. Desafíos y Urgencias Para el tercer Milenio; Arenas, F., Cáceres, G., Eds.; Universidad Católica de Chile: Santiago, Chile, 2001.

21. Andrade, B.; Arenas, F.; Guijón, R. Revisión crítica del marco institucional y legal chileno de ordenamiento territorial: El caso de la zona costera. Rev. Geogr. Norte Gd. 2008, 41, 23-48. [CrossRef]

22. Gines, A. Análisis y Diagnóstico de la Operacionalización de la Politica Nacional de Uso del Borde Costero a Través de las Macrozonificaciones Costeras Regionales de Chile. Bachelor's Thesis, Chile University, Santiago, Chile, 2015.

23. CONAF (Corporación Nacional Forestal). Programa Nacional para la Conservación de Humedales insertos en el Sistema Nacional de Áreas Silvestres Protegidas del Estado. 2010. Available online: https://www.conaf.cl/wp-content/files_mf/1369258173 CEIHUMEDALES.pdf (accessed on 9 February 2021).

24. RAMSAR Official Webpage. Available online: https://www.ramsar.org/wetland/chile (accessed on 8 February 2020).

25. MMA (Ministerio de Medio Ambiente). In Plan Nacional de Protección de Humedales 2018-2022; Ministerio del Medio Ambiente: Santiago, Chile, 2018. Available online: https://mma.gob.cl/wp-content/uploads/2018/11/Plan_humedales_Baja_confrase_ VERSION-DEFINITIVA.pdf (accessed on 12 February 2020).

26. MMA. Las Áreas Protegidas de Chile; División de Recursos Naturales y Biodiversidad Ministerio de Medio Ambiente: Santiago, Chile, 2015. Available online: http://bdrnap.mma.gob.cl/recursos/privados/Recursos/CNAP/Consultoria/2015_LasAPs_ 2ed.pdf (accessed on 28 June 2021).

27. BCN (Biblioteca del Congreso Nacional de Chile). Ley 17288, Legisla Sobre Monumentos Nacionales; Modifica las Leyes 16.617 y 16.719; Deroga el Decreto Ley 651, de 17 De Octubre de 1925; Ministry of Cultures. 1970. Available online: https: / / www.bcn.cl/leychile/navegar?idNorma=28892 (accessed on 28 April 2021). 
28. CMN (Consejo de Monumentos Nacionales). 2021. Available online: https://www.monumentos.gob.cl/monumentos/ definicion/santuarios-de-la-naturaleza (accessed on 8 April 2021).

29. BCN (Biblioteca del Congreso Nacional de Chile). Ley 21.202, Modifica Diversos Cuerpos Legales Con el Objetivo de Proteger Los Humedales Urbanos; ID 1141461. Ministry of the Environment (MMA). 2020. Available online: https://www.bcn.cl/leychile/ navegar?idNorma=1141461 (accessed on 28 June 2021).

30. De Martonne, E. Aréisme et indice d'aridité. CR Acad. Sci. 1926, 182, 1395-1398.

31. Galleguillos, S. Análisis Geomorfológico y Cartografía de Procesos Geológicos Peligrosos en Chañaral (Atacama, Chile). Bachelor's Thesis, Universidad de Atacama, Atacama, Chile, 2018.

32. Vargas, G.; Ortega, C. El aluvión de marzo de 2015, El Niño y los mayores episodios históricos en Chañaral de las Ánimas, Atacama. In Aluviones y Resiliencia de Atacama. Aportes Desde la Transdisciplina Académica; Vargas, G., Pérez, S., Aldunce, P., Eds.; Social-Ediciones: Santiago, Chile, 2018; pp. 35-92. ISBN 978-956-19-1116-1.

33. Campos, R. Análisis de Marejadas Históricas y Recientes en las Costas de Chile. Ph.D. Thesis, Universidad de Valparaíso, Valparaiso, Chile, 2016; p. 210.

34. Campos, R.; Beyá, J.; Mena, M. Cuantificación de los Daños Históricos a Infraestructura Costera por Marejadas en las Costas de Chile. In Proceedings of the XXII Congreso Chileno de Ingeniería Hidráulica, Santiago, Chile, 21-23 October 2015.

35. MMA (Ministerio del Medio Ambiente). Volumen 6: Vulnerabilidad en humedales. In Determinación del Riesgo de los Impactos del Cambio Climático en las Costas de Chile; Ministerio de Medio Ambiente: Santiago, Chile, 2019; p. 144.

36. Schurr, B.; Asch, G.; Hainzl, S.; Bedford, J.; Hoechner, A.; Palo, M.; Wang, R.; Moreno, M.; Bartsch, M.; Zhang, Y.; et al. Gradual unlocking of plate boundary controlled initiation of the 2014 Iquique earthquake. Nature 2014, 512, 299-302. [CrossRef]

37. Métois, M.; Vigny, C.; Socquet, A. Interseismic coupling, megathrust earthquakes and seismic warms along the Chilean subduction zone $\left(38^{\circ}-18^{\circ}\right.$ S). Pure Appl. Geophys. 2016, 173, 1431-1449. [CrossRef]

38. Lomnitz, C. Major Earthquakes of Chile: A Historical Survey, 1535-1960. Seismol. Res. Lett. 2004, 75, 368-378. [CrossRef]

39. Ruiz, S.; Madariaga, R. Historical and recent large megathrust earthquakes in Chile. Tectonophysics 2018, 733, 37-56. [CrossRef]

40. Abad, M.; Izquierdo, T.; Cáceres, M.; Bernárdez, E.; Rodriguez-Vidal, J. Coastal boulder deposit as evidence of an ocean-wide prehistoric tsunami originated on the Atacama Desert coast (northern Chile). Sedimentology 2020, 67, 1505-1528. [CrossRef]

41. Satake, K.; Heidarzadeh, M.; Quiroz, M.; Cienfuegos, R. History and features of trans-oceanic tsunamis and implications for paleo-tsunami studies. Earth Sci. Rev. 2020, 202, 103112. [CrossRef]

42. Vargas, G.; Farías, M.; Carretier, S.; Tassara, A.; Baize, S.; Melnick, D. Coastal uplift and tsunami effects associated to the 2010 Mw8. 8 Maule earthquakes in Central Chile. Andean Geol. 2011, 38, 219-238.

43. Sandoval, N.; Valdovinos-Zarges, C.; Oyanedel, J.P.; Vásquez, D. Impacts of coseismic uplift caused by the $20108.8 \mathrm{Mw}$ earthquake on the macrobenthic community of the Tubul-Raqui Saltmarsh (Chile). Estuar. Coast. Shelf Sci. 2019, 226, 106278. [CrossRef]

44. Rodríguez, M.P.; Carretier, S.; Charrier, R.; Saillard, M.; Regard, V.; Hérail, G.; Hall, S.; Farber, D.; Audin, L. Geochronology of pediments and marine terraces in north-central Chile and their implications for Quaternary uplift in the Western Andes. Geomorphology 2013, 180-181, 33-46. [CrossRef]

45. Martinod, J.; Regard, V.; Riquelme, R.; Aguilar, G.; Guillaume, B.; Carretier, S.; Cortés-Aranda, J.; Leanni, L.; Hérail, G. Pleistocene uplift, climate and morphological segmentation of the Northern Chile coasts ( $\left.24^{\circ} \mathrm{S}-32^{\circ} \mathrm{S}\right)$ : Insights from cosmogenic $10 \mathrm{Be}$ dating of paleoshorelines. Geomorphology 2016, 274, 78-91. [CrossRef]

46. Valdés-Pineda, R.; Cañón, J.; Valdés, J.B. Multi-decadal 40-to 60-year cycles of precipitation variability in Chile (South America) and their relationship to the AMO and PDO signals. J. Hydrol. 2018, 556, 1153-1170. [CrossRef]

47. Cerda, M.; Evangelista, H.; Valdes, J.; Siffedine, A.; Boucher, H.; Nogueira, J.; Nepomuceno, A.; Ortlieb, L. A new 20th century lake sedimentary record from the Atacama Desert/Chile reveals persistent PDO (Pacific Decadal Oscillation) impact. J. S. Am. Earth Sci. 2019, 95, 102302. [CrossRef]

48. Rutllant, J.; Fuenzalida, H.; Aceituno, P. Climate dynamics along the arid northern coast of Chile: The 1997-1998 Dinámica del Clima de la Región de Antofagasta (DICLIMA) experiment. JGR Atmos. 2003, 108, D17. [CrossRef]

49. Strub, P.T. Coastal ocean circulation off western South America. The global coastal ocean. Reg. Stud. Synth. 1998, $273-315$.

50. Canevari, P.; Davidson, I.; Blanco, D.E.; Castro, G.; Bucher, E.H. Los Humedales de América del Sur. Una Agenda Para la Conservación de la Biodiversidad y Las Politicas de Desarrollo; Wetlands International: Wageningen, The Netherlands, 2001.

51. Rutllant, J.; Fuenzalida, H.; Torres, R.; Figueroa, D. Interacción océano-atmósfera-tierra en la Región de Antofagasta (Chile, 23 S): Experimento DICLIMA. Rev. Chil. Hist. Nat. 1998, 71, 405-427.

52. Valdés-Pineda, R.; Pizarro, R.; García-Chevesich, P.; Valdés, J.B.; Olivares, C.; Vera, M.; Balocchi, F.; Pérez, F.; Vallejos, C.; Fuentes, R.; et al. Water governance in Chile: Availability, management and climate change. J. Hydrol. 2014, 519, 2538-2567. [CrossRef]

53. DGA. Available online: www.dga.cl (accessed on 15 February 2021).

54. Cereceda, P.; Larrain, H.; Lázaro, P.; Osses, P.; Schemenauer, R.S.; Fuentes, L. Campos de tillandsias y niebla en el desierto de Tarapacá. Rev. Geogr. Norte Gd. 1999, 26, 3-13.

55. Izquierdo, T.; de Las Heras, P.; Márquez, A. Vegetation indices changes in the cloud forest of La Gomera Island (Canary Islands) and their hydrological implications. Hydrol. Process. 2011, 25, 1531-1541. [CrossRef]

56. Stanton, D.E. Small scale fog-gradients change epiphytic lichen shape and distribution. Bryologist 2015, 118, 241-244. [CrossRef]

57. Bonnail, E.; Lima, R.C.; Turrieta, G.M. Trapping fresh sea breeze in desert? Health status of Camanchaca, Atacama's fog. Environ. Sci. Pollut. Res. 2018, 25, 18204-18212. [CrossRef] 
58. Figueroa, R.; Suarez, M.L.; Andreu, A.; Ruiz, V.H.; Vidal-Abarca, M.R. Caracterización ecológica de humedales de la zona semiarida en Chile central. Gayana 2009, 73, 76-94. [CrossRef]

59. Peña, H.; Salazar, C. Calidad de Aguas; Serie de Documentos Técnicos; SIT No 2; Technical Report; DGA: Santiago, Chile, 1993.

60. Amberes Consultora. Antecedentes para la Creación del Santuario de la Naturaleza en el Humedal de la Desembocadura del Río Lluta; Unpublished Technical Report; Comisión Nacional de Medio Ambiente y Municipalidad de Arica: Arica, Chile, $2007 ;$ p. 128.

61. BCN (Biblioteca del Congreso Nacional de Chile). Decreto 106. Ministry of Cultures. Declara Santuario de la Naturaleza de la Desembocadura del río Lluta, Ubicado en la Comuna de Arica. ID1008418. 2009. Available online: https://www.bcn.cl/leychile/ navegar?idNorma=1008418 (accessed on 28 June 2021).

62. García, J.; Senner, N.; Norambuena, H.; Schmitt, F. Atlas de las Aves Playeras de Chile: Sitios Importantes Para su Conservación; Universidad Santo Tomás: Santiago, Chile, 2017; p. 274.

63. Ecoterra ONG. Levantamiento, Sistematización y Elaboración de Informe Técnico Para la Solicitud de Declaración de Santuario de la Naturaleza del Sector denominado Desembocadura Rio Camarones, Comuna de Camarones, Región de Arica y Parinacota; Unpublished Technical Report; Ministry of Environment (MMA): Rio de Janeiro, Brazil, 2019; p. 183.

64. Hernández, J.; Estades, C.; Faúndez, L.; Herreros de Lartundo, J. Biodiversidad Terrestre de la Región de Arica y Parinacota, 1st ed.; Universidad de Chile y Ministry of Environment (MMA): Santiago, Chile, 2014; p. 413.

65. Salazar, C. Situación de los Recursos Hídricos en Chile; Unpublished Technical Report; The Nippon Foundation: Santiago, Chile, 2003; p. 109.

66. Dirección General de Aguas (DGA). Diagnóstico y Clasificación de los Cursos y Cuerpos de Agua Según Objetivos de Calidad: Cuenca del río Loa; Unpublished Technical Report; Ministry of Public Works (MOP): Santiago, Chile, 2004; p. 149.

67. Ramírez, C.; Álvarez, M. Hydrophilic Flora and Vegetation of the Coastal Wetlands of Chile. In The Ecology and Natural History of Chilean Saltmarshes; Fariña, J.M., Camaño, A., Eds.; Springer: Cham, Switzerland, 2017; pp. 71-103.

68. BCN (Biblioteca del Congreso Nacional de Chile). Decreto 660. Ministry of National Assets. Destina al Ministerio de Bienes Nacionales Inmueble Ubicado en la Desembocadura del Río Loa, I Región Tarapacá, y II Región de Atacama. ID 249083.2006. Available online: https: / / www.bcn.cl/leychile/navegar?idNorma=249083 (accessed on 28 June 2021).

69. Fundación Kennedy Web. Available online: https:/ / fundacionkennedy.cl (accessed on 11 March 2020).

70. Quiroz, R. Funcionamiento Hidrológico del Humedal Ribereño María Isabel, Sector Bajo Río Copiapó, Región de Atacama. Bachelor's Thesis, Universidad de Atacama, Copiapó, Chile, 2016; p. 130.

71. Dirección General de Aguas (DGA). Diagnóstico y Clasificación de los Cursos y Cuerpos de Agua Según Objetivos de Calidad: Cuenca del río Copiapó; Unpublished Technical Report; Ministry of Public Works (MOP): Santiago, Chile, 2004; p. 122.

72. Fundación Chile. Monitoreo Ambiental Humedal Desembocadura del Río Copiapó; Informe Anual 2010; Unpublished Technical Report; Compañía Minera Contractual Candelaria: Santiago, Chile, 2010; p. 67.

73. Fundación Chile. Monitoreo Ambiental Humedal Desembocadura del Río Copiapó; Informe Anual 2012; Unpublished Technical Report; Compañía Minera Contractual Candelaria: Santiago, Chile, 2012; p. 54.

74. BCN (Biblioteca del Congreso Nacional de Chile). Decreto 360. Ministerio de Defensa Nacional y Subsecretaría de Marina. Declara Área Marina y Costera Protegida "Punta Morro-Desembocadura Río Copiapó" un Sector de la Costa de la III Región de Atacama Entre Punta Morro y la Desembocadura del Río Copiapó y Terrenos de Playa Fiscales de la Isla Chata Chica e Isla Grande. ID 235281. 2007. Available online: https:/ / www.bcn.cl/leychile/navegar?idNorma=235281 (accessed on 28 June 2021).

75. Photosintesis Consul. Levantamiento y Sistematización de Información Para la Declaración Santuario de la Naturaleza del Sector Denominado Humedal Costero de Totoral. Informe Final; Unpublished Technical Report; Ministry of Environment (MMA): Atacama, Chile, 2019; p. 225.

76. Comunidad Agrícola de Totoral. Expediente de Postulación "Santuario de la Naturaleza Humedal Costero de Totoral"; Unpublished Technical Report; Ministry of Environment (MMA): Atacama, Chile, 2020; p. 122.

77. Olivares, F.; Cepeda, A.; Treiman, P. Consultoría para la Recopilación de Información Sobre la Biodiversidad y la Situación Socio-Económica en Apoyo a la Elaboración del Anteproyecto de la Norma Secundaria de Calidad Ambiental para la Protección de las Aguas de la Cuenca del Río Huasco; Unpublished Technical Report; Gestión y Monitoreo Ambiental Consultores: Vallenar, Chile, 2007 ; p. 198.

78. Sociedad Agrícola Quebrada Honda. Solicitud de Declaración de Santuario de la Naturaleza Humedal Costero de Carrizal Bajo, Región de Atacama; Unpublished Technical Report; Ministry of Environment (MMA): Atacama, Chile, 2018; p. 180.

79. BCN (Biblioteca del Congreso Nacional de Chile). Decreto 39. Ministry of Environment (MMA). Declara Santuario de la Naturaleza Humedal Costero Carrizal Bajo. ID 1148721. 2020. Available online: https://www.bcn.cl/leychile/navegar? idNorma $=1148721$ (accessed on 28 June 2021).

80. Dura, T.; Hemphill-Haley, E.; Sawai, Y.; Horton, B.P. The application of diatoms to reconstruct the history of subduction zone earthquakes and tsunamis. Earth-Sci. Rev. 2016, 152, 181-197. [CrossRef]

81. Valdovinos, C.; Sandoval, N.; Vasquez, D.; Olmos, V. The Tubul-Raqui Coastal Wetland: A Chilean Ecosystem of High Conservation Value Severely Disturbed by the 2010 Earthquake. In The Ecology and Natural History of Chilean Saltmarshes; Fariña, J.M., Camaño, A., Eds.; Springer: Cham, Switzerland, 2017; pp. 293-327.

82. Fariña, J.M.; He, Q.; Silliman, B.R.; Bertness, M.D. Bottom-up and top-down human impacts interact to affect a protected coastal Chilean marsh. Ecology 2016, 97, 640-648. [CrossRef] 
83. González-Alfaro, J.; Vargas, G.; Ortlieb, L.; González, G.; Ruiz, S.; Báez, J.C.; Man-deng-Yogo, M.; Caquineau, S.; Álvarez, G.; Del Campo, F.; et al. Abrupt increase in the coastal uplift and earthquake rate since $\sim 40 \mathrm{ka}$ at the northern Chile seismic gap in the Central Andes. Earth Planet. Sci. Lett. 2018, 502, 32-45. [CrossRef]

84. Izquierdo, T.; Carrasco, G.; Rodríguez-Vidal, J.; Ruiz, F.; Abad, M. Geomorfología y evolución geológica reciente del litoral del Parque Nacional Pan de Azúcar (norte de Chile). Geogaceta 2020, 67, 111-114.

85. Muñoz, D.A. Geoarqueología de Tsunamis Históricos en la Costa Hiperárida de Arica y Parinacota. Bachelor's Thesis, Universidad de Chile, Santiago, Chile, 2019; p. 131.

86. Catalán, P.A.; Aránguiz, R.; González, G.; Tomita, T.; Cienfuegos, R.; González, J.; Shrivastava, M.N.; Kumagai, K.; Mokrani, C.; Cortés, P.; et al. The 1 April 2014 Pisagua tsunami: Observations and modeling. Geophys. Res. Lett. 2015, 42, 2918-2925. [CrossRef]

87. Bobillier, C. Terremoto de Atacama año 1922. Bol. Serv. Sismol. Chile 1926, 16, 1-44.

88. Forch, M. Registro Geológico de Tsunamis Holocenos en el Humedal de Carrizal Bajo (Atacama, Norte de Chile). Bachelor's Thesis, Universidad de Atacama, Copiapó, Chile, 2020; p. 145.

89. Fernández-Navarro, R. Cambios en la Configuración Costera del Sector Puerto Viejo-Las Salinas Durante el Holoceno Reciente (Atacama, norte de Chile). Bachelor's Thesis, Universidad de Atacama, Copiapó, Chile, 2016; p. 143.

90. Liew, S.C.; Gupta, A.; Wong, P.P.; Kwoh, L.K. Recovery from a large tsunami mapped over time: The Aceh coast, Sumatra. Geomorphology 2010, 114, 520-529. [CrossRef]

91. Richmond, B.; Szczuciński, W.; Chagué-Goff, C.; Goto, K.; Sugawara, D.; Witter, R.; Tappin, D.R.; Jaffe, B.; Fujino, S.; Nishimura, Y.; et al. Erosion, deposition and landscape change on the Sendai coastal plain, Japan, resulting from the 11 March 2011 Tohoku-oki tsunami. Sediment. Geol. 2012, 282, 27-39. [CrossRef]

92. Contreras-López, M.; Winckler, P.; Sepúlveda, I.; Andaur-Álvarez, A.; Cortés-Molina, F.; Guerrero, C.J.; Mizobe, C.E.; Igualt, F.; Breuer, W.; Beyá, J.F.; et al. Field Survey of the 2015 Chile Tsunami with Emphasis on Coastal Wetland and Conservation Areas. Pure Appl. Geophys. 2016, 173, 349-367. [CrossRef]

93. Cienfuegos, R.; Campino, J.R.; Gironás, J.; Almar, R.; Villagrán, M. River Mouths and Coastal Lagoons in Central Chile. In The Ecology and Natural History of Chilean Saltmarshes; Fariña, J.M., Camaño, A., Eds.; Springer International Publishing: Cham, Switzerland, 2017; pp. 14-46.

94. González, P.; Ortiz, J.; Jerez, R.; Pavez, M.; Arcos, D. Effects of the 2010 Tsunami on the Mataquito River Wetland. In The Ecology and Natural History of Chilean Saltmarshes; Fariña, J.M., Camaño, A., Eds.; Springer: Cham, Switzerland, 2017; pp. 265-292.

95. Srinivas, H.; Nakagawa, Y. Environmental implications for disaster preparedness: Lessons Learnt from the Indian Ocean Tsunami. J. Environ. Manag. 2008, 89, 4-13. [CrossRef] [PubMed]

96. Ramachandran, S.; Anitha, S.; Balamurugan, V.; Dharanirajan, K.; Vendhan, K.E.; Divien, M.I.P.; Vel, A.S.; Hussain, I.S.; Udayaraj, A. Ecological impact of tsunami on Nicobar Islands (Camorta, Katchal, Nancowry and Trinkat). Curr. Sci. 2005, 89, 195-200.

97. Chagué-Goff, C.; Niedzielski, P.; Wong, H.K.Y.; Szczuciński, W.; Sugawara, D.; Goff, J. Environmental impact assessment of the 2011 Tohoku-oki tsunami on the Sendai Plain. Sediment. Geol. 2012, 282, 175-187. [CrossRef]

98. Chávez-Villavicencio, C.; Tabilo-Valdivieso, E.; Jofré-Pérez, E. Tsunami effects on Coquimbo Bay wetland water-bird species composition, associated with the 2015 Mw8.4 Illapel earthquake (northern Chile). Latin Am. J. Aquat. Res. 2019, 47, 845-852. [CrossRef]

99. Day, J.W.; Christian, R.R.; Boesch, D.M.; Yáñez-Arancibia, A.; Morris, J.; Twilley, R.R.; Naylor, L.; Schaffner, L.; Stevenson, C. Consequences of Climate Change on the Ecogeomorphology of Coastal Wetlands. Estuaries Coasts 2008, 31, 477-491. [CrossRef]

100. Tedesco, L.P.; Wanless, H.R.; Scusa, L.A.; Andrew Risi, J.; Gelsanliter, S. Impacts of hurricane Andrew on the coastal zones of Florida and Louisiana: 22-26 August 1992. J. Coast. Res. 1995, 21, 1-364.

101. White, E.; Kaplan, D. Restore or retreat? Saltwater intrusion and water management in coastal wetlands. Ecosyst. Health Sustain. 2017, 3, e01258. [CrossRef]

102. Flynn, K.; McKee, K.; Mendelssohn, I. Recovery of freshwater marsh vegetation after a saltwater intrusion event. Oecologia 1995, 103, 63-72. [CrossRef]

103. Wang, X.; Wang, W.; Tong, C. A review on impact of typhoons and hurricanes on coastal wetland ecosystems. Acta Ecol. Sin. 2016, 36, 23-29. [CrossRef]

104. IPCC. Contribution of Working Groups I, II and III to the Fifth Assessment Report of the Intergovernmental Panel on Climate Change. In Climate Change 2014: Synthesis Report; Core Writing Team, Pachauri, R.K., Meyer, L.A., Eds.; IPCC: Geneva, Switzerland, 2014; p. 151.

105. Vicuña, S.; Vargas, X.; Boisier, J.P.; Mendoza, P.A.; Gómez, T.; Vásquez, N.; Cepeda, J. (Eds.) Impacts of Climate Change on Water Resources in Chile. In Water Resources of Chile; Springer: Cham, Switzerland, 2021; pp. 347-363.

106. Rojas, O.; Latorre, T.; Pacheco, F.; Araya, M.; Lopez, J.; Oyarzun, E.S. Inundaciones fluviales en cuencas costeras mediterráneas de Chile: Recurrencia, factores físicos y efectos hidrogeomorfológicos de su gestión. In La Zona Costera en Chile: Adaptacion y Planificacion Para la Resiliencia; Hidalgo, R., Martinez, C., Henriquez, C., Arenas, F., Rangel-Buitrago, N., Contreras-Lopez, M., Eds.; Instituto de Geografía-Serie GEOlibros: Santiago, Chile, 2019; pp. 285-307.

107. Vargas, G.; Rutllant, J.; Ortlieb, L. ENSO tropical-extratropical climate teleconnections and mechanisms for Holocene debris flows along the hyperarid coast of western South America $\left(17^{\circ}-24^{\circ}\right.$ S). Earth Planet. Sci. Lett. 2006, 249, 467-483. [CrossRef]

108. Ortega, C.; Vargas, G.; Rutllant, J.A.; Jackson, D.; Méndez, C. Major hydrological regime change along the semiarid western coast of South America during the early Holocene. Quat. Res. 2012, 78, 513-527. [CrossRef] 
109. Abad, M.; Fernández, R.; Izquierdo, T. Geomorphic effects and sedimentological record of flash floods in the Copiapó River salt marsh (Atacama coast, Northern Chile). In Proceedings of the 19th EGU General Assembly, EGU2017, Viena, Austria, 23-28 April 2017; p. 10191.

110. Ortega, C.; Vargas, G.; Rojas, M.; Dezileau, L.; Ortlieb, L. Extreme ENSO-driven torrential rainfalls at the southern edge of the Atacama Desert during the Late Holocene and their projection into the 21st century. Glob. Planet. Chang. 2019, 175, $226-237$. [CrossRef]

111. Izquierdo, T.; Abad, M.; Gómez, Y.; Gallardo, D.; Rodríguez-Vidal, J. The March 2015 catastrophic flood event and its impacts in the city of Copiapó (southern Atacama Desert). An integrated analysis to mitigate future mudflow derived damages. J. S. Am. Earth Sci. 2021, 105, 102975. [CrossRef]

112. Ortlieb, L. Eventos El Niño y episodios lluviosos en el desierto de Atacama: El registro de los últimos dos siglos. Bull. Inst. Fr. Études Andin. 1995, 24, 519-537.

113. Campos-Ortega, H.; Díaz, G.; Campos, C. Aportes sedimentarios de los ríos Lluta y San José en la zona costera de la rada de Arica, Chile. Idesia 2007, 25, 37-48. [CrossRef]

114. Carvajal, H. Análisis y Cartografía Multievento de Peligrosidad del Núcleo Urbano de Copiapó ante Inundaciones y Aluviones. Bachelor's Thesis, Universidad de Atacama, Atacama, Chile, 2018.

115. Izquierdo, T.; Rivera, A.; Abad, M. Identification of Extraordinary Floods in the Late Holocene Fluvial Deposits of the Copiapó River (Southern Atacama Desert, Chile); INQUA: Dublin, Ireland, 2019.

116. Perez, G.; Pagliero, L.; McIntyre, N.; Aitken, D.; Rivera, D. Evaluation of Climate Change Risks Faced by the Mining Industry in Chile: Spatiotemporal Analysis of Extreme Precipitation for 2035-2065. In Proceedings of the EGU General Assembly 2021, EGU21-10500, online, 19-30 April 2021. [CrossRef]

117. Freund, M.B.; Henley, B.J.; Karoly, D.J.; McGregor, H.V.; Abram, N.J.; Dommenget, D. Higher frequency of Central Pacific El Niño events in recent decades relative to past centuries. Nat. Geosci. 2019, 12, 450-455. [CrossRef]

118. Izquierdo, T.; Abad, N.; Larrondo, L. Paleohydrology of Late Quaternary floods in the Atacama Desert and their paleoclimate implications. In Proceedings of the 19th EGU General Assembly, EGU2017, Viena, Austria, 23-28 April 2017 ; p. 10261.

119. Ostroski, A.; Connolly, R.M.; Sievers, M. Evaluating multiple stressor research in coastal wetlands: A systematic review. Mar. Environ. Res. 2021, 164, 105239. [CrossRef]

120. Aguilera, M.A.; Aburto, J.A.; Bravo, L.; Broitman, B.R.; García, R.A.; Gaymer, C.F.; Gelcich, S.; López, B.A.; Montecino, V.; Pauchard, A.; et al. (Eds.) Chapter 29. Chile: Environmental status and future perspectives. In World Seas: An Environmental Evaluation, 2nd ed.; Europe, The Americas and West Africa; Academic Press: Cambridge, CA, USA; Elsevier: Amsterdam, The Netherlands, 2019; Volume 1, pp. 673-702. [CrossRef]

121. Bonnail, E.; Cruz Hernández, P.; Galleguillos, S.; Izquierdo, T.; Abad, M. La contaminación metálica en la bahía de Chañaral (norte de Chile): Retrospección, prospección y proyección. Geogaceta 2020, 67, 59-62.

122. Fariña, J.M.; Castilla, J.C. Temporal variation in the diversity and cover of sessile species in rocky intertidal communities affected by copper mine tailings in northern Chile. Mar. Pollut. Bull. 2001, 42, 554-568. [CrossRef]

123. Izquierdo, T.; Bonnail, E.; Abad, M.; Dias, M.I.; Prudêncio, M.I.; Marques, R.; Rodríguez-Vidal, J.; Ruiz, F. Pollution and potential risk assessment of flood sediments in the urban area of the mining Copiapó basin (Atacama Desert). J. S. Am. Earth Sci. 2020, 103, 102714. [CrossRef]

124. Copaja, S.V.; Muñoz, F.J. Heavy metals concentration in sediment of Lluta river basin. J. Chil. Chem. Soc. 2018, 63, 3878-3883. [CrossRef]

125. Arica al Día. Available online: https:/ / www.aricaldia.cl/ (accessed on 11 January 2011).

126. Sandi, S.G.; Saco, P.M.; Saintilan, N.; Wen, L.; Riccardi, G.; Kuczera, G.; Willgoose, G.; Rodríguez, J.F. Detecting inundation thresholds for dryland wetland vulnerability. Adv. Water Resour. 2019, 128, 168-182. [CrossRef]

127. Duguid, A.; Barnetson, J.; Clifford, B.; Pavey, C.; Albrecht, D.; Risler, J.; McNellie, M. A report to the Australian Government. Department of the Environment and Heritage on the inventory and significance of wetlands in the arid NT. In Wetlands in the arid Northern Territory; Northern Territory Government Department of Natural Resources, Environment and the Arts: Alice Springs, Australia, 2005; p. 359.

128. Seto, K.; Parnell, S.; Elmqvist, T. A Global Outlook on Urbanization. Urbanization Biodiversity and Ecosystem Services: Challenges and Opportunities; Springer: Dordrecht, The Netherlands, 2013. [CrossRef]

129. Rojas, C.; Munizaga, J.; Rojas, O.; Martínez, C.; Pino, J. Urban development versus wetland loss in a coastal Larin American city: Lesson for sustainable land use planning. Land Use Policy 2019, 80, 47-56. [CrossRef] 